\title{
Minireviews
}

\section{Predictive Value of Parkinsonian Primates in Pharmacologic Studies: A Comparison between the Macaque, Marmoset, and Squirrel Monkey ${ }^{\S}$}

\author{
Nicolas Veyres, Adjia Hamadjida, and Philippe Huot \\ Centre de Recherche du Centre Hospitalier de l'Université de Montréal (N.V.),Montreal Neurological Institute (A.H.,P.H.), and \\ Department of Neurology and Neurosurgery, McGill University (P.H.), Montreal, Quebec, Canada
}

Received December 13, 2017; accepted March 6, 2018

\section{ABSTRACT}

The 1-methyl-4-phenyl-1,2,3,6-tetrahydropyridine (MPTP)-lesioned primate is the gold-standard animal model of Parkinson disease (PD) and has been used to assess the effectiveness of experimental drugs on dyskinesia, parkinsonism, and psychosis. Three species have been used in most studies-the macaque, marmoset, and squirrel monkey-the last much less so than the first two species; however, the predictive value of each species at forecasting clinical efficacy, or lack thereof, is poorly documented. Here, we have reviewed all the published literature detailing pharmacologic studies that assessed the effects of experimental drugs on dyskinesia, parkinsonism, and psychosis in each of these species and have calculated their predictive value of success and failure at the clinical level. We found that, for dyskinesia, the macaque has a positive predictive value of $87.5 \%$ and a false-positive rate of $38.1 \%$, whereas the marmoset has a positive predictive value of $76.9 \%$ and a false-positive rate of $15.6 \%$. For parkinsonism, the macaque has a positive predictive value of $68.2 \%$ and a false-positive rate of $44.4 \%$, whereas the marmoset has a positive predictive value of $86.9 \%$ and a false-positive rate of $41.7 \%$. No drug that alleviates psychosis in the clinic has shown efficacy at doing so in the macaque, whereas the marmoset has $100 \%$ positive predictive value. The small number of studies conducted in the squirrel monkey precluded us from calculating its predictive efficacy. We hope our results will help in the design of pharmacologic experiments and will facilitate the drug discovery and development process in PD.

\section{Introduction}

Since its accidental discovery (Davis et al., 1979; Langston et al., 1983), 1-methyl-4-phenyl-1,2,3,6-tetrahydropyridine (MPTP) has been used extensively to model Parkinson disease (PD) in a breadth of nonhuman primates, enabling the investigation of anatomic (Jan et al., 2000; Zeng et al., 2008), behavioral (Pessiglione et al., 2004a,b), neurochemical (Soghomonian et al., 1994; Huot et al., 2008), and other aspects of the disease. The MPTP-lesioned primate has also been invaluable in the search for effective antidyskinetic and antiparkinsonian agents. A review article previously examined the translational predictive value of the MPTP-lesioned primate for the development of antidyskinetic drugs, but it was published more than a decade ago (Fox et al., 2006a), and many drugs have since been tested both in the primate and in clinical settings. This previous review did not examine the translational predictive value of the MPTP-lesioned

P.H. holds research support from Parkinson Canada, Fonds de Recherche Québec - Santé, Natural Sciences and Engineering Research Council of Canada, and the Weston Brain Institute.

https://doi.org/10.1124/jpet.117.247171.

S This article has supplemental material available at jpet.aspetjournals.org. primate when it relates to the effect of drugs on parkinsonian disability or dopaminergic psychosis, nor did it look at differences between different primate species when it comes to predicting the clinical effectiveness of an experimental molecule.

We have therefore conducted a thorough and unbiased review of the literature to compare the predictive effectiveness of different MPTP-lesioned primate species on the clinical effectiveness of potential antidyskinetic, antiparkinsonian and antipsychotic agents.

We believe this review comes at a critical time given that it has recently been suggested that some primate species might be more suited than others to conduct behavioral pharmacologic research (Porras et al., 2012); also, there have been several failures of high-profile drugs in clinical trials (Cook et al., 2014; Bespalov et al., 2016), emphasizing the need to use the best animal model possible in preclinical settings to maximize chances of success when translating to the clinic.

\section{Materials and Methods}

Three nonhuman primate species have been used in most experiments to determine the antidyskinetic, antiparkinsonian, and antipsychotic 


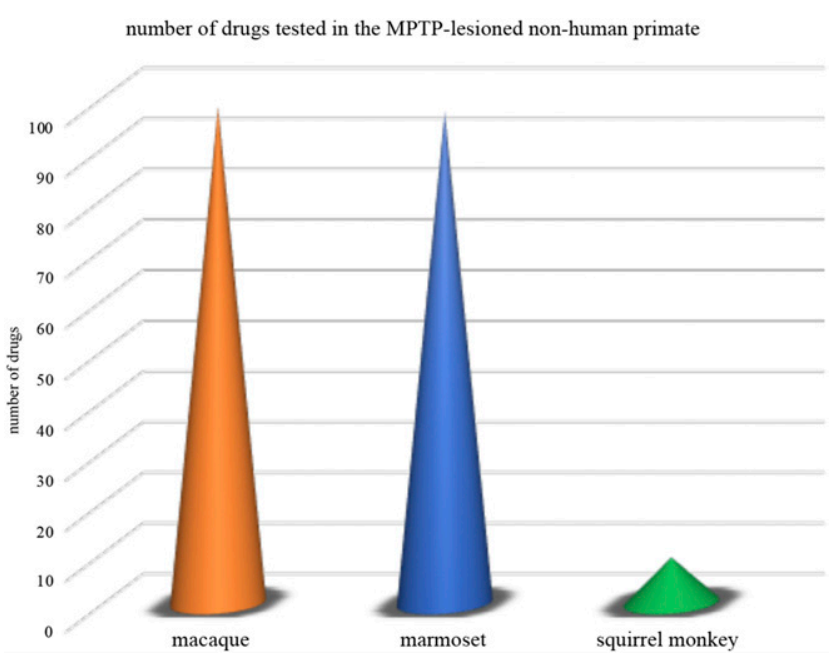

Fig. 1. A total of 98 experimental drugs were tested in the MPTP-lesioned macaque, 97 in the MPTP-lesioned marmoset, and nine in the MPTPlesioned squirrel monkey.

effect of experimental drugs: the macaque [both cynomolgus (Di Paolo et al., 1986) and rhesus (Burns et al., 1983), Macaca fascicularis and Macaca mulatta, respectively], the common marmoset (Jenner et al., 1984) (Callithrix jacchus), and the common squirrel monkey (Langston et al., 1984) (Saimiri sciureus). For each of these three primate species, we have reviewed all the studies that reported their effect, or lack thereof, on dyskinesia, parkinsonism, and psychosis. We then sought which of these drugs tested in the nonhuman primate underwent clinical testing and compared their preclinical and clinical effects and calculated different predictive values (see Endpoints).

Inclusion Criteria. The literature search spans from 1983, when the first MPTP-lesioned nonhuman primate was engineered (Burns et al., 1983), until December 10, 2017. Studies published after this date, either online or in print format, are not included.

Only drugs whose preclinical and clinical efficacy, or lack thereof, were reported in peer-reviewed articles are included in this article. Results disseminated solely through abstracts or conference proceedings are therefore not reported here. We are aware that not all studies conducted on parkinsonian primates have been published and that the results of some clinical trials have not been disseminated through peer-reviewed journals; by choosing to include only studies and reports that were published in peer-reviewed journals, we may be introducing a selection bias in our analysis. For instance, although it has been studied in humans (NCT00034814, NCT00108667), the clinical effectiveness of talampanel will not be discussed here, as the results of the clinical trials where it was assessed were not published in peer-reviewed scientific journals. In addition, we have excluded L-3,4-dihydroxyphenylalanine (L-DOPA) and inhibitors of L-aromatic amino acid decarboxylase [e.g., benserazide (Rinne et al., 1975) and carbidopa (Marsden et al., 1973)] from our analysis, as these were used in almost all studies cited here to reverse parkinsonism and induce dyskinesia.

Research Methods. Literature review was conducted primarily through the United States National Library of Medicine database, accessed via PubMed. The search engine Google was used to complete the literature review and to access articles not indexed in the National Library of Medicine database. The following terms were used to perform the literature search: abnormal involuntary movements, chorea, cynomolgus, dyskinesia, dyskinetic, dystonia, hallucinations, hyperactivity, hyperkinesia, L-DOPA, levodopa, macaque, marmoset, monkey, MPTP, nonhuman primate, $\mathrm{PD}$, parkinsonian, parkinsonism, primate, psychosis, rhesus, squirrel monkey, visual hallucinations.

Definition of Efficacy. Throughout our literature search, a reduction in dyskinesia/psychosis was considered to have occurred only if statistical significance was reached; trends were not number of drugs assessed in the clinic or clinically-approved that were tested in the MPTP-lesioned non-human primate

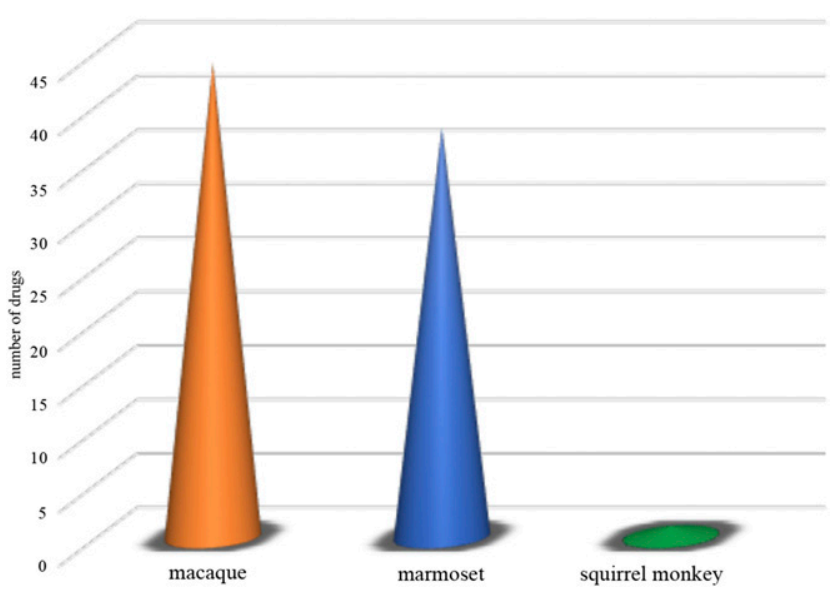

Fig. 2. A total of 44 drugs that are either clinically approved or that underwent clinical testing in PD were tested in the MPTP-lesioned macaque, 38 in the MPTP-lesioned marmoset, and one in the MPTPlesioned squirrel monkey.

considered. A drug was considered to have antiparkinsonian benefit if it alleviated parkinsonism as monotherapy or as an adjunct to L-DOPA. Impulse-control disorders (Weintraub et al., 2010) were not considered a psychotic manifestation.

Several studies, especially in the macaque, were performed that administered drugs (e.g., cabergoline) to reduce the development of dyskinesia and then conducted postmortem experiments; we have included these studies in our analysis, even if their primary endpoint was not determination of pharmacologic efficacy. Studies reporting the effects of experimental drugs on rotational behavior in the hemi-MPTPlesioned primate (e.g., Vermeulen et al., 1995) were not included.

In some instances, conflicting results were obtained with some drugs (e.g., studies encountered a therapeutic benefit), whereas others did not reach similar conclusions; whenever this happened, we calculated the predictive values using "best result" (i.e., the one that showed a therapeutic effect), weighing in the methods used in the studies (Gad, 2009), if applicable. For instance, in the case of preladenant, phase 2 studies have found antiparkinsonian efficacy (Hauser et al., 2011; Factor et al., 2013), whereas phase 3 studies did not (Hauser et al., 2015; Stocchi et al., 2017); but in one instance, the active comparator, rasagiline (Hauser et al., 2015), was also ineffective, despite proven antiparkinsonian benefit in randomized-controlled trials (Parkinson Study Group, 2005; Rascol et al., 2005), somewhat casting doubt on study conclusion. In this case, we considered that preladenant exerted antiparkinsonian benefit.

Endpoints. By comparing the outcomes of the primate studies on dyskinesia, parkinsonism, and psychosis, we have calculated, for each species, the positive predictive value, the negative predictive value, and the false-positive rate.

Here, we define the positive predictive value of a species as the percentage of cases for which a primate species has correctly predicted that an antidyskinetic or antiparkinsonian benefit would be achieved in the clinic. For the positive predictive value (eq. 1), the denominator was the number of drugs for which a therapeutic effect was achieved in the clinic, whereas the numerator was the number of these drugs that showed efficacy in the primate:

$$
\frac{\text { number of molecules that showed effect in the primate }}{\text { number of clinically - effective molecules }}
$$

Here, we define the negative predictive value of a species as the percentage of cases for which a primate species has correctly predicted that a lack of antidyskinetic or antiparkinsonian benefit 
TABLE 1

Drugs tested in the MPTP-lesioned macaque

The number $(n)$ of studies reporting the effect of each drug is in brackets.

\begin{tabular}{|c|c|c|c|c|}
\hline Drug & Dyskinesia & Parkinsonism & Psychosis & References \\
\hline 17- $\alpha$-Estradiol $[n=1]$ & ne & ne & na & Gomez-Mancilla and Bedard (1992b) \\
\hline $17-\beta$-Estradiol $[n=2]$ & $\sqrt{ }$ & $\sqrt{ }$ & na & Gomez-Mancilla and Bedard (1992b), Bélanger et al. (2003a) \\
\hline $\begin{array}{l}\text { (-)-3-(3-Hydroxyphenyl)-N-n- } \\
\text { propylpiperone }\end{array}$ & $\mathrm{Ne}$ & $\sqrt{ }$ & na & Gomez-Mancilla and Bedard (1991) \\
\hline$[n=1]$ & & & & \\
\hline $\begin{array}{l}\text { (+)-4-Propyl-9-hydroxynaphthoxazine } \\
{[n=7]}\end{array}$ & $\mathrm{Ne}$ & $\sqrt{ }$ & na & $\begin{array}{l}\text { Gomez-Mancilla and Bedard (1991, 1992a), Luquin et al. (1992, } \\
\text { 1993b), Blanchet et al. (1993, 1994), Belluzzi et al. (1994) }\end{array}$ \\
\hline$(-)-O S U-6162[n=1]$ & $\sqrt{ }$ & ne & na & Hadj Tahar et al. (2001) \\
\hline $5-\mathrm{MDOT}[n=1]$ & $\sqrt{ }$ & $\mathrm{de}$ & na & Gomez-Mancilla and Bedard (1993) \\
\hline 8-OH-DPAT $[n=1]$ & $\sqrt{ }$ & ne & na & Munoz et al. (2008) \\
\hline A-77,636 $[n=2]$ & & $\sqrt{ }$ & na & Blanchet et al. $(1993,1996 b)$ \\
\hline A-86,929 $[n=1]$ & & $\sqrt{ }$ & na & Grondin et al. (1997) \\
\hline ADL-5510 $[n=1]$ & $\sqrt{ }$ & & na & Koprich et al. (2011) \\
\hline $\mathrm{AFQ}-056[n=1]$ & $\sqrt{ }$ & $\sqrt{ }$ & na & Grégoire et al. (2011) \\
\hline Amantadine $[n=7]$ & $\sqrt{ }$ & de & na & $\begin{array}{l}\text { Blanchet et al. (1998), Bibbiani et al. (2005b), Rylander et al. (2010), } \\
\text { Bezard et al. (2013b), Grégoire et al. (2013), Ko et al. (2014b), Shen } \\
\text { et al. (2015) }\end{array}$ \\
\hline Anpirtoline $[n=1]$ & $\sqrt{ }$ & de & na & Bézard et al. (2013a) \\
\hline Apomorphine $[n=8]$ & ne & $\sqrt{ }$ & na & $\begin{array}{l}\text { Filion et al. (1991), Luquin et al. (1993a), Akai et al. (1995), } \\
\text { Blanchet et al. (1997), Doan et al. (1999), Silverdale et al. (2002), } \\
\text { Bibbiani et al. (2003, 2005a) }\end{array}$ \\
\hline AQW-051 $[n=1]$ & $\sqrt{ }$ & $\sqrt{ }$ & na & Di Paolo et al. (2014) \\
\hline Atropine $[n=1]$ & ne & $\sqrt{ }$ & na & Gomez-Mancilla et al. (1991) \\
\hline Baclofen $[n=1]$ & ne & de & na & Gomez-Mancilla and Bedard (1993) \\
\hline BP-897 $[n=1]$ & $\sqrt{ }$ & ne & na & Bézard et al. (2003) \\
\hline Bromocriptine $[n=9]$ & ne & $\sqrt{ }$ & na & $\begin{array}{l}\text { Bédard et al. (1986), Falardeau et al. (1988), Gagnon et al. (1990, } \\
\text { 1995), Rouillard et al. (1990), Gomez-Mancilla and Bedard (1991), } \\
\text { Blanchet et al. (1993), Gomez-Mancilla et al. (1993), Belluzzi et al. } \\
\text { (1994) }\end{array}$ \\
\hline Cabergoline $[n=20]$ & ne & $\sqrt{ }$ & na & $\begin{array}{l}\text { Grondin et al. (1996), Morissette et al. (1998, 1999, 2010), Calon } \\
\text { et al. (1999, 2000, 2002), Goulet et al. (1999, 2000), Hadj Tahar } \\
\text { et al. (2000b), Bélanger et al. (2003b), Samadi et al. (2008a,b,c, } \\
\text { 2010), Ouattara et al. (2009, 2010, 2011), Riahi et al. (2011) }\end{array}$ \\
\hline $\mathrm{CE}[=1]$ & ne & $\sqrt{ }$ & na & Cao et al. (2007) \\
\hline Citalopram $[n=1]$ & $\sqrt{ }$ & de & na & Fidalgo et al. (2015) \\
\hline CI-1041 $[n=14]$ & $\sqrt{ }$ & ne & na & $\begin{array}{l}\text { Hadj Tahar et al. (2004), Morissette et al. (2006a,b, 2010), Samadi } \\
\text { et al. (2008a,b,c, 2010), Ouattara et al. (2009, 2010, 2011), Tamim } \\
\text { et al. (2010), Riahi et al. (2011) }\end{array}$ \\
\hline Clonidine $[n=2]$ & $\sqrt{ }$ & $\sqrt{ }$ & na & Gomez-Mancilla et al. (1991), Gomez-Mancilla and Bedard (1993) \\
\hline Clozapine $[n=1]$ & $\sqrt{ }$ & ne & na & Grondin et al. (1999b) \\
\hline CLR-151 $[n=1]$ & $\sqrt{ }$ & de & $\sqrt{ }$ & Koprich et al. (2013) \\
\hline $\begin{array}{l}\text { Co-101,244/PD-174,494 } \\
\quad[n=1]\end{array}$ & $\sqrt{ }$ & ne & na & Blanchet et al. (1999) \\
\hline CP-94,253 $[n=1]$ & ne & ne & na & Munoz et al. (2008) \\
\hline CP-101,606 $[n=1]$ & ne & $\sqrt{ }$ & na & Steece-Collier et al. (2000) \\
\hline CX-516 $[n=1]$ & de & ne & na & Konitsiotis et al. (2000) \\
\hline CY-208,243 $[n=8]$ & ne & $\sqrt{ }$ & na & $\begin{array}{l}\text { Gomez-Mancilla and Bedard (1991, 1992a), Gomez-Mancilla et al. } \\
\text { (1992a, 1993), Blanchet et al. (1993), Gagnon et al. (1993, 1995), } \\
\text { Luquin et al. (1993b) }\end{array}$ \\
\hline DHEA $[n=2]$ & ne & $\sqrt{ }$ & na & Bélanger et al. (2003a, 2006) \\
\hline Diazepam $[\mathrm{n}=1]$ & $\sqrt{ }$ & ne & na & Gomez-Mancilla and Bedard (1993) \\
\hline Dipraglurant $[n=1]$ & $\sqrt{ }$ & ne & na & Bezard et al. (2014) \\
\hline Docosahexaenoic acid $[n=5]$ & $\sqrt{ }$ & ne & na & $\begin{array}{l}\text { Samadi et al. (2006), Mahmoudi et al. (2009), Tamim et al. (2010), } \\
\text { Riahi et al. (2012), Grégoire et al. (2015) }\end{array}$ \\
\hline Eltoprazine $[n=3]$ & $\sqrt{ }$ & de & na & Bezard et al. (2013b), Pinna et al. (2016), Ko et al. (2017) \\
\hline Entacapone $[n=1]$ & ne & $\sqrt{ }$ & na & Huot et al. (2013) \\
\hline Ethosuximide $[n=1]$ & ne & $\sqrt{ }$ & na & Gomez-Mancilla et al. (1992b) \\
\hline F-15,599 $[n=1]$ & $\sqrt{ }$ & ne & na & Huot et al. (2015b) \\
\hline Famotidine $[n=1]$ & $\sqrt{ }$ & $\sqrt{ }$ & na & Johnston et al. (2010d) \\
\hline Fenobam $[n=2]$ & $\sqrt{ }$ & $\sqrt{ }$ & na & Rylander et al. (2010), Ko et al. (2014b) \\
\hline Fipamezole $[n=1]$ & $\sqrt{ }$ & $\sqrt{ }$ & na & Johnston et al. (2010c) \\
\hline GYKI-47,261 $[n=1]$ & $\sqrt{ }$ & ne & na & Bibbiani et al. (2005b) \\
\hline Idazoxan $[n=2]$ & $\sqrt{ }$ & $\sqrt{ }$ & na & Bezard et al. (1999), Grondin et al. (2000) \\
\hline Istradefylline $[n=3]$ & ne/de & $\sqrt{ }$ & na & Grondin et al. (1999a), Bibbiani et al. (2003, Ko et al. (2016) \\
\hline JL-18 $[n=1]$ & $\sqrt{ }$ & de & na & Hadj Tahar et al. (2000a) \\
\hline $\mathrm{L}-745,870[n=1]$ & $\sqrt{1}$ & ne & na & Huot et al. (2012b) \\
\hline L-tryptophan $[n=1]$ & $\sqrt{ }$ & de & na & Ko et al. (2014a) \\
\hline Levetiracetam $[n=1]$ & $\sqrt{ }$ & ne & na & Bezard et al. (2004) \\
\hline LY-235,959 $[n=1]$ & $\sqrt{ }$ & ne & na & Papa and Chase (1996) \\
\hline MDL-100,453 [n= 1] & $\sqrt{ }$ & ne & na & Blanchet et al. (1999) \\
\hline Meperidine $[n=1]$ & $\sqrt{ }$ & ne & na & Gomez-Mancilla and Bedard (1993) \\
\hline Methysergide $[n=1]$ & $\sqrt{ }$ & de & na & Gomez-Mancilla and Bedard (1993) \\
\hline
\end{tabular}


TABLE 1-Continued

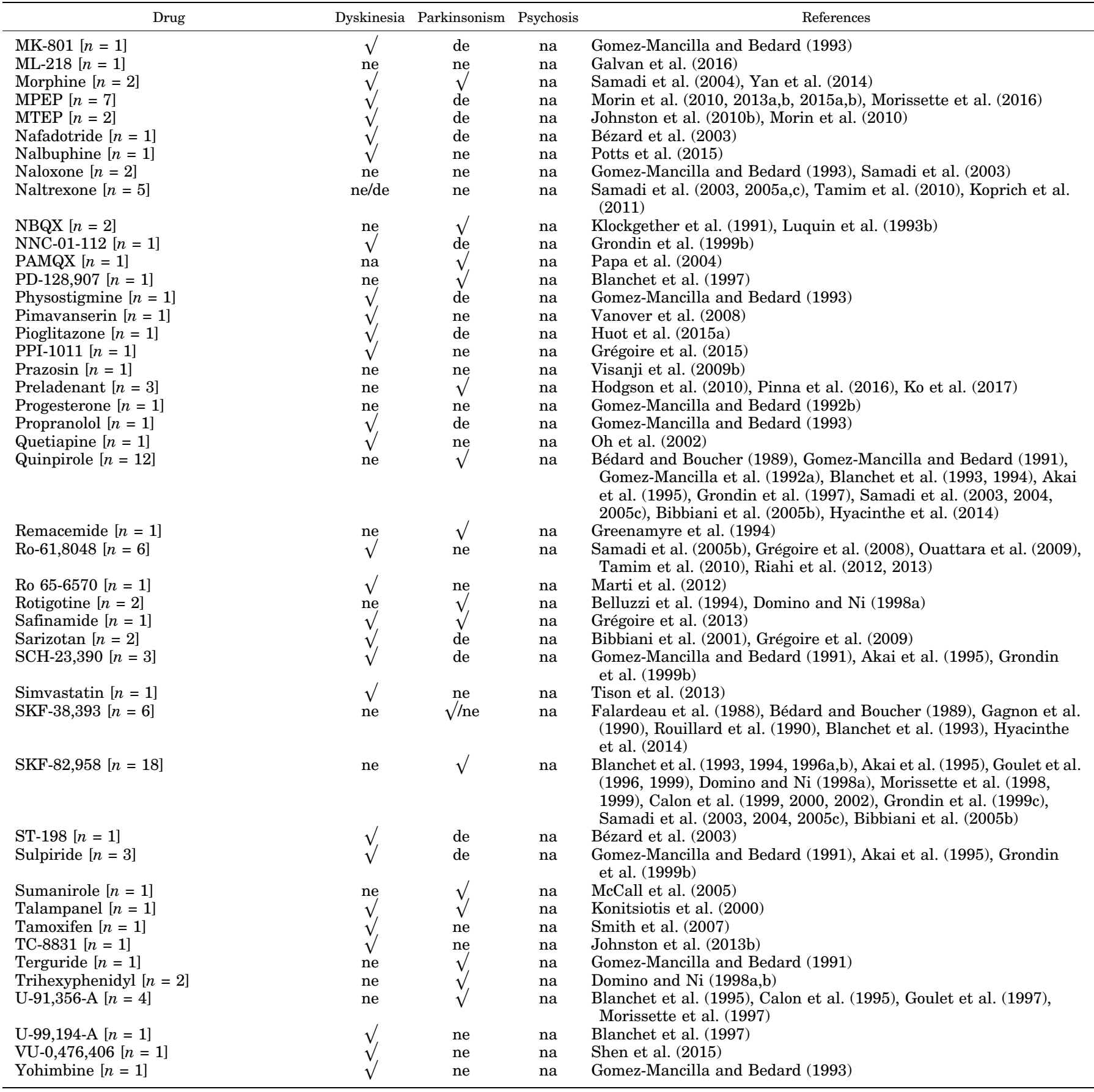

de, deleterious; na, not assessed; ne, not effective; $\sqrt{ }$, effective.

would be achieved in the clinic. For the negative predictive value (eq. 2), the denominator was the number of drugs for which a therapeutic effect was not achieved in the clinic, and the numerator was the number of these drugs that did not show efficacy in the primate:

$$
\frac{\text { number of molecules that did not show effect in the primate }}{\text { number of clinically - ineffective molecules }}
$$

Here, we define the false-positive rate of a species as the percentage of cases for which a primate species has incorrectly 
TABLE 2

Drugs tested in the MPTP-lesioned marmoset

The number (n) of studies reporting the effect of each drug is in brackets.

\begin{tabular}{|c|c|c|c|c|}
\hline Drug & Dyskinesia & Parkinsonism & Psychosis & References \\
\hline $\begin{array}{l}\Delta-(9)-\mathrm{THC} \\
{[n=1]}\end{array}$ & ne & $\sqrt{ }$ & na & van Vliet et al. (2008) \\
\hline $\begin{array}{l}(+)-\mathrm{PHNO} \\
{[n=2]}\end{array}$ & ne & $\sqrt{ }$ & na & Nomoto et al. (1987), Close et al. (1990) \\
\hline $\begin{array}{l}\text { (+)-N-n-propyl-3-(3-hydroxyphenyl)-piperidine [(+)-3PPP }] \\
\quad[n=1]\end{array}$ & ne & $\sqrt{ }$ & na & Close et al. (1990) \\
\hline $\begin{array}{l}\text { (-)-N-n-propyl-3-(3-hydroxyphenyl)-piperidine (-)-3PPP } \\
\quad[n=1]\end{array}$ & ne & ne & $\mathrm{Na}$ & Close et al. (1990) \\
\hline$(-)-\mathrm{N}-0437[n=1]$ & ne & $\sqrt{ }$ & na & Löschmann et al. (1989) \\
\hline (-)-OSU-6162 [n=1] & $\sqrt{ }$ & ne & na & Ekesbo et al. (1997) \\
\hline $\begin{array}{l}\text { 2-amino-5,6-dihydroxytetralin (N,N-dipropyl A-5,6-DTN) } \\
{[n=1]}\end{array}$ & ne & $\sqrt{ }$ & na & Close et al. (1990) \\
\hline $\mathrm{R}-(-)-11-\mathrm{OH}-\mathrm{NPa}[n=1]$ & ne & $\sqrt{ }$ & na & Lincoln et al. (2016) \\
\hline A- $66,359[n=1]$ & ne & de & na & Gnanalingham et al. (1995c) \\
\hline A-77,636 $[n=4]$ & ne & $\sqrt{ }$ & na & $\begin{array}{l}\text { Kebabian et al. (1992), Pearce et al. (1995, 1999), } \\
\text { Smith et al. (2002a) }\end{array}$ \\
\hline A-86,929 $[n=3]$ & ne & $\sqrt{ }$ & na & $\begin{array}{l}\text { Shiosaki et al. (1996), Pearce et al. (1999), } \\
\text { Treseder et al. (2000) }\end{array}$ \\
\hline $\mathrm{ABT}-431[n=1]$ & ne & $\sqrt{ }$ & na & Shiosaki et al. (1996) \\
\hline Amantadine $[n=3]$ & $\sqrt{ }$ & ne & de & $\begin{array}{l}\text { Hill et al. (2004b), Visanji et al. (2006), Kobylecki } \\
\text { et al. (2011) }\end{array}$ \\
\hline Aplindore $[n=1]$ & ne & $\sqrt{ }$ & na & Jackson et al. (2010) \\
\hline Apomorphine $[n=6]$ & ne & $\sqrt{ }$ & ne & $\begin{array}{l}\text { Löschmann et al. (1992), Pearce et al. (1995), Fox } \\
\text { et al. (2001), Maratos et al. (2003), Visanji et al. } \\
\text { (2006), Lincoln et al. (2016) }\end{array}$ \\
\hline Atropine $[n=2]$ & ne & $\sqrt{ }$ & ne & Close et al. (1990), Jackson et al. (2014) \\
\hline Benztropine $[n=1]$ & ne & $\sqrt{ }$ & na & Close et al. (1990) \\
\hline rasofensine $[n=1]$ & ne & $\sqrt{ }$ & na & Pearce et al. (2002) \\
\hline Bromocriptine $[n=3]$ & ne & $\sqrt{ }$ & na & Close et al. (1990), Pearce et al. $(1995,1998)$ \\
\hline BTS-74,398 $[n=2]$ & ne & $\sqrt{/ \text { ne }}$ & na & Hansard et al. (2002b, 2004) \\
\hline Bupropion $[n=2]$ & ne & $\sqrt{\text { lne }}$ & na & Hansard et al. (2002b, 2011) \\
\hline Clozapine $[n=1]$ & $\sqrt{ }$ & ne & $\sqrt{ }$ & Visanji et al. (2006) \\
\hline CP-101,606 $[n=1]$ & ne & $\sqrt{ }$ & na & Nash et al. (2004) \\
\hline $\mathrm{CPP}[n=1]$ & ne & $\sqrt{ }$ & na & Löschmann et al. (1991) \\
\hline CY-208,243 [n=2] & ne & $\sqrt{ }$ & na & Temlett et al. $(1988,1989)$ \\
\hline Cyproheptadine $[n=1]$ & $\sqrt{ }$ & ne & ne & Henry et al. (2001) \\
\hline Entacapone $[n=4]$ & ne & $\sqrt{ }$ & na & Smith et al. (1997, 2003, 2005), Zubair et al. (2007) \\
\hline Fipamezole $[n=1]$ & $\sqrt{ }$ & $\sqrt{ }$ & na & Savola et al. (2003) \\
\hline GBR-12,909 $[n=2]$ & ne & $\sqrt{ }$ & na & Hansard et al. (2002a,b) \\
\hline Haloperidol $[n=1]$ & $\sqrt{ }$ & de & $\sqrt{ }$ & Visanji et al. (2006) \\
\hline Idazoxan $[n=1]$ & $\sqrt{ }$ & $\sqrt{ }$ & na & Henry et al. (1999) \\
\hline IEM-1460 $[n=1]$ & $\sqrt{ }$ & ne & na & Kobylecki et al. (2010) \\
\hline ifenprodil $[n=1]$ & ne & $\sqrt{ }$ & na & Nash et al. (2000) \\
\hline Imetit $[n=1]$ & $\sqrt{ }$ & ne & na & Gomez-Ramirez et al. (2006) \\
\hline Immepip $[n=1]$ & $\sqrt{ }$ & ne & na & Gomez-Ramirez et al. (2006) \\
\hline Istradefylline $[n=6]$ & ne & $\sqrt{ }$ & na & $\begin{array}{l}\text { Kanda et al. }(1998 a, b, 2000), \text { Uchida et al. } \\
(2014,2015 a, b)\end{array}$ \\
\hline $\mathrm{J}-113,397[n=1]$ & $\sqrt{ }$ & ne & na & Visanji et al. (2008) \\
\hline JNJ-27,063,699 [n= 1] & ne & $\sqrt{ }$ & na & Philippens et al. (2014) \\
\hline Levetiracetam $[n=3]$ & $\sqrt{ }$ & ne & na & Hill et al. $(2003,2004 a, b)$ \\
\hline LY-141,865 [ $n=1]$ & ne & $\sqrt{ }$ & na & Nomoto et al. (1985) \\
\hline $\operatorname{MDMA}[n=1]$ & $\sqrt{ }$ & $\sqrt{ }$ & na & Iravani et al. (2003) \\
\hline Melanocyte-inhibiting factor $[n=1]$ & ne & ne & na & Katzenschlager et al. (2007) \\
\hline Mianserin $[n=1]$ & $\sqrt{ }$ & de & $\sqrt{ }$ & Hamadjida et al. (2018) \\
\hline Mirtazapine $[n=1]$ & $\sqrt{ }$ & ne & $\sqrt{ }$ & Hamadjida et al. (2017) \\
\hline Modafinil $[n=2]$ & ne & $\sqrt{ }$ & na & Jenner et al. (2000), van Vliet et al. (2008) \\
\hline $\mathrm{N}-0437[n=1]$ & ne & $\sqrt{ }$ & na & Löschmann et al. (1989) \\
\hline $\begin{array}{l}\text { N-methyl scopolamine } \\
\quad[n=1]\end{array}$ & ne & $\sqrt{ }$ & na & Jackson et al. (2014) \\
\hline Nabilone $[n=1]$ & $\sqrt{ }$ & ne & na & Fox et al. (2002) \\
\hline Naltrexone $[n=1]$ & $\sqrt{ }$ & ne & na & Henry et al. (2001) \\
\hline Naltrindole $[N=1]$ & $\sqrt{ }$ & ne & na & Henry et al. (2001) \\
\hline Neostigmine $[n=1]$ & ne & $\sqrt{ }$ & na & Jackson et al. (2014) \\
\hline Nisoxetine $[n=1]$ & ne & $\sqrt{/ \mathrm{de}}$ & na & Hansard et al. (2002b) \\
\hline $\operatorname{NBQX}[n=1]$ & ne & $\sqrt{ }$ & na & Löschmann et al. (1991) \\
\hline Nomifensine $[n=2]$ & ne & $\sqrt{ }$ & na & Close et al. (1990), Hansard et al. (2002b) \\
\hline Oxotremorine $[n=1]$ & ne & de & na & Jackson et al. (2014) \\
\hline Pardoprunox $[n=3]$ & $\sqrt{ }$ & $\sqrt{ }$ & na & $\begin{array}{l}\text { Johnston et al. (2010a), Jones et al. (2010), } \\
\text { Tayarani-Binazir et al. (2010a) }\end{array}$ \\
\hline
\end{tabular}


TABLE 2-Continued

\begin{tabular}{|c|c|c|c|c|}
\hline Drug & Dyskinesia & Parkinsonism & Psychosis & References \\
\hline Pergolide $[n=5]$ & ne & $\sqrt{ }$ & na & $\begin{array}{l}\text { Pearce et al. (1995), Maratos et al. (2003), Fox } \\
\text { et al. (2006b), Uchida et al. (2015a,b) }\end{array}$ \\
\hline Physostigmine $[n=1]$ & ne & de & na & Jackson et al. (2014) \\
\hline Quetiapine $[n=1]$ & $\sqrt{ }$ & ne & $\sqrt{ }$ & Visanji et al. (2006) \\
\hline Quinpirole $[n=8]$ & ne & $\sqrt{ }$ & na & $\begin{array}{l}\text { Nomoto et al. (1988), Close et al. (1990), } \\
\text { Löschmann et al. (1992), Gnanalingham et al. } \\
\text { (1995a,b), Pearce et al. (1995), Kanda et al. } \\
\text { (2000), Treseder et al. (2000) }\end{array}$ \\
\hline$(R)-(+)-O H D P A T ~[n=1]$ & $\sqrt{ }$ & de & na & Iravani et al. (2006) \\
\hline R-MDMA $[n=1]$ & $\sqrt{ }$ & ne & $\sqrt{ }$ & Huot et al. (2011) \\
\hline Raclopride $[n=4]$ & $\sqrt{ }$ & de & na & $\begin{array}{l}\text { Löschmann et al. (1992), Gnanalingham et al. } \\
\text { (1995c), Ekesbo et al. (1997), Smith et al. } \\
\text { (2002a) }\end{array}$ \\
\hline Rauwolscine $[n=1]$ & $\sqrt{ }$ & ne & na & Henry et al. (1999) \\
\hline RGFP-109 $[n=1]$ & $\sqrt{ }$ & ne & na & Johnston et al. (2013a) \\
\hline Rotigotine $[n=3]$ & ne & $\sqrt{ }$ & na & Rose et al. (2007), Stockwell et al. $(2009,2010)$ \\
\hline $\mathrm{S}-32,504[n=2]$ & ne & $\sqrt{ }$ & na & Millan et al. (2004), Hill et al. (2006) \\
\hline S-33,084 $[n=3]$ & ne & $\sqrt{ }$ & na & $\begin{array}{l}\text { Silverdale et al. (2004), Hill et al. (2006), Visanji } \\
\text { et al. (2009a) }\end{array}$ \\
\hline S-MDMA $[n=1]$ & de & $\sqrt{ }$ & ne & Huot et al. (2011) \\
\hline $\begin{array}{l}\text { S,S-hydroxybupropion } \\
{[n=1]}\end{array}$ & ne & $\sqrt{ }$ & na & Hansard et al. (2011) \\
\hline SB-224,289-A $[n=1]$ & ne & ne & na & Jackson et al. (2004) \\
\hline $\mathrm{SCH}-23,390[n=4]$ & ne & de & na & $\begin{array}{l}\text { (Temlett et al. (1988), Löschmann et al. (1992), } \\
\text { Gnanalingham et al. (1995c), Smith et al. } \\
\text { (2002a) }\end{array}$ \\
\hline $\mathrm{SKF}-83,565[n=1]$ & ne & $\sqrt{ }$ & na & Gnanalingham et al. (1995a) \\
\hline SKF-83,959 $[n=3]$ & ne & $\sqrt{ }$ & na & Gnanalingham et al. (1995a,b,c) \\
\hline SKF-99,101-H $[n=1]$ & $\sqrt{ }$ & ne/de & na & Jackson et al. (2004) \\
\hline $\begin{array}{l}\text { SNC-80 } \\
{[n=1]}\end{array}$ & ne & $\sqrt{ }$ & na & Hille et al. (2001) \\
\hline $\begin{array}{l}\text { ST-1535 } \\
{[n=1]}\end{array}$ & ne & $\sqrt{ }$ & na & Rose et al. (2006) \\
\hline $\begin{array}{l}\text { Sulpiride } \\
{[n=2]}\end{array}$ & ne & de & na & Temlett et al. (1988), Jones et al. (2010) \\
\hline Terguride $[n=1]$ & ne & $\sqrt{ }$ & na & Lange et al. (1992) \\
\hline Topiramate $[n=2]$ & $\sqrt{ }$ & ne & na & Silverdale et al. (2005), Kobylecki et al. (2011) \\
\hline $\begin{array}{l}\text { Trihexyphenidyl } \\
{[n=1]}\end{array}$ & ne & $\sqrt{ }$ & na & Jackson et al. (2014) \\
\hline URB-597 $[n=1]$ & ne & ne & ne & Johnston et al. (2011) \\
\hline UWA-101 $[n=2]$ & ne & $\sqrt{ }$ & ne & Huot et al. (2012a), Johnston et al. (2012) \\
\hline UWA-121 $[n=1]$ & ne & $\sqrt{ }$ & ne & Huot et al. (2014) \\
\hline UWA-122 [n=1] & $\sqrt{ }$ & $\sqrt{ }$ & ne & Huot et al. (2014) \\
\hline Yohimbine $[n=1]$ & $\sqrt{ }$ & ne & na & Henry et al. (1999) \\
\hline
\end{tabular}

de, deleterious; na, not assessed; ne, not effective; $\sqrt{ }$, effective.

predicted that a lack of antidyskinetic or antiparkinsonian benefit would be achieved in the clinic. For the false-positive rate (eq. 3), the denominator was the number of drugs for which a therapeutic effect was not achieved in the clinic; the numerator was the number of these clinically ineffective drugs that were deemed to be effective in the primate:

\section{Results}

\section{Pharmacologic Targets}

Several pharmacologic targets have been modulated in studies performed in the MPTP-lesioned macaque and the MPTP-lesioned marmoset. In contrast, only dopaminergic, 
TABLE 3

Drugs tested in the MPTP-lesioned squirrel monkey

The number $(n)$ of studies reporting the effect of each drug is in brackets.

\begin{tabular}{|c|c|c|c|c|}
\hline Drug & Dyskinesia & Parkinsonism & Psychosis & References \\
\hline ABT-089 $[n=1]$ & $\sqrt{ }$ & ne & na & Zhang et al. (2014) \\
\hline ABT-107 $[n=1]$ & $\sqrt{ }$ & ne & na & Zhang et al. (2013) \\
\hline ABT-126 $[n=1]$ & $\sqrt{ }$ & ne & na & Zhang et al. (2015) \\
\hline ABT-894 $[n=3]$ & $\sqrt{ }$ & ne & na & Zhang et al. $(2013,2014,2015)$ \\
\hline BP-897 $[n=1]$ & $\sqrt{ }$ & $\mathrm{de}$ & na & Hsu et al. (2004) \\
\hline Nicotine $[n=4]$ & $\sqrt{ }$ & ne & na & Quik et al. (2007, 2013a,b), Zhang et al. (2015) \\
\hline TC-8831 $[n=1]$ & $\sqrt{ }$ & ne & na & Zhang et al. (2013) \\
\hline $\mathrm{U} 50-488[n=1]$ & $\sqrt{ }$ & de & na & Cox et al. (2007) \\
\hline Varenicline $[n=1]$ & $\sqrt{ }$ & ne & na & Zhang et al. (2013) \\
\hline
\end{tabular}

de, deleterious; na, not assessed; ne, not effective; $\sqrt{ }$, effective.

opioidergic and cholinergic targets have been assessed in studies conducted in the MPTP-lesioned squirrel monkey (see Supplemental Table 1 for the pharmacologic profile of all molecules that have been tested in the MPTP-lesioned primate).

A total of 98 different molecules were assessed in the MPTPlesioned macaque, 97 in the MPTP-lesioned marmoset, and nine in the MPTP-lesioned squirrel monkey (Fig. 1). Of all the molecules tested in the MPTP-lesioned primate, 64 have been assessed at the clinical level or are clinically approved. Of these, 44 were tested in the macaque, 38 in the marmoset, and one in the squirrel monkey (Fig. 2). Because very few drugs have been tested in the MPTP-lesioned squirrel monkey compared with the macaque and the marmoset, we do not discuss it further in the text, but we have nevertheless included it in the tables.

We have summarized our research results in tables:

- Table 1: drugs tested in the MPTP-lesioned macaque

- Table 2: drugs tested in the MPTP-lesioned marmoset

- Table 3: drugs tested in the MPTP-lesioned squirrel monkey

- Table 4: drugs tested in the MPTP-lesioned primate that were tested in the clinic or are clinically-available

In each table, the drugs are listed in numerical or alphabetical order.

We have also summarized our results in figures:

- Figure 1: number of drugs tested in the MPTP-lesioned nonhuman primate

- Figure 2: number of drugs assessed in the clinic or clinically approved that were tested in the MPTPlesioned nonhuman primate

- Figure 3: antidyskinetic positive predictive value of the MPTP-lesioned nonhuman primate

- Figure 4: antidyskinetic negative predictive value of the MPTP-lesioned nonhuman primate

- Figure 5: antidyskinetic false positive rate of the MPTPlesioned nonhuman primate

- Figure 6: antiparkinsonian positive predictive value of the MPTP-lesioned nonhuman primate

- Figure 7: antiparkinsonian negative predictive value of the MPTP-lesioned nonhuman primate

- Figure 8: antiparkinsonian false positive rate of the MPTP-lesioned nonhuman primate

- Figure 9: worsening of parkinsonism positive predictive value of the MPTP-lesioned nonhuman primate.

\section{Prediction of Antidyskinetic Effect}

Of the 64 drugs that were tested in the clinic and in the MPTP-lesioned primate, 22 showed antidyskinetic effect in clinical trials, no antidyskinetic effect was found or reported for 36 drugs, and four drugs showed a deleterious effect on dyskinesia severity (see Supplemental Table 2 for details).

MPTP-Lesioned Macaque. Of the 22 drugs that demonstrated an antidyskinetic effect in clinical settings, 16 were tested in the macaque, and an antidyskinetic effect was obtained with 14 (87.5\% positive predictive value, Fig. 3). Of the 36 drugs for which no antidyskinetic effect was found or reported in the clinic, 21 were tested in the macaque. No antidyskinetic effect was encountered or reported with 13 (61.9\% negative predictive efficacy, Fig. 4); an antidyskinetic action was found with eight (38.1\% false-positive rate, Fig. 5). Of the four drugs that had a deleterious effect on dyskinesia severity in the clinic, two were tested in the macaque, and an exacerbation of dyskinesia could not be demonstrated in either case.

MPTP-Lesioned Marmoset. Of the 22 drugs that demonstrated an antidyskinetic effect in clinical settings, 13 were tested in the marmoset, and an antidyskinetic effect was obtained with 10 (76.9\% positive predictive value, Fig. 3). Of the 36 drugs for which no antidyskinetic effect was found or reported, 22 were tested in the marmoset, and the absence of antidyskinetic effect was identified in 19 (86.4\% negative predictive value, Fig. 4), whereas an antidyskinetic action was found with three (15.6\% false-positive rates Fig. 5). Of the four drugs that had a deleterious effect on dyskinesia severity, three were tested in the marmoset, but an exacerbation of dyskinesia could not be demonstrated in any case.

\section{Prediction of Antiparkinsonian Action}

Of the 64 drugs that were tested in the clinic and in the MPTP-lesioned primate, 34 showed an antiparkinsonian effect in clinical trials; no antiparkinsonian effect was found or reported for 24 drugs, and five drugs were found to have a deleterious effect on parkinsonian disability (see Supplemental Table 3 for details).

MPTP-Lesioned Macaque. Of the 34 drugs that showed antiparkinsonian effect in clinical trials, 22 were tested in the macaque, and an antiparkinsonian benefit was obtained with 15 (68.2\% positive predictive value, Fig. 6 ). Of the 24 drugs for which no antiparkinsonian effect was found or reported, 18 were tested in the macaque, and no antiparkinsonian effect was encountered or reported with six (33.3\% negative predictive value, Fig. 7), whereas antiparkinsonian action was 
TABLE 4

Drugs tested in the MPTP-lesioned primate that were tested in the clinic or are clinically available

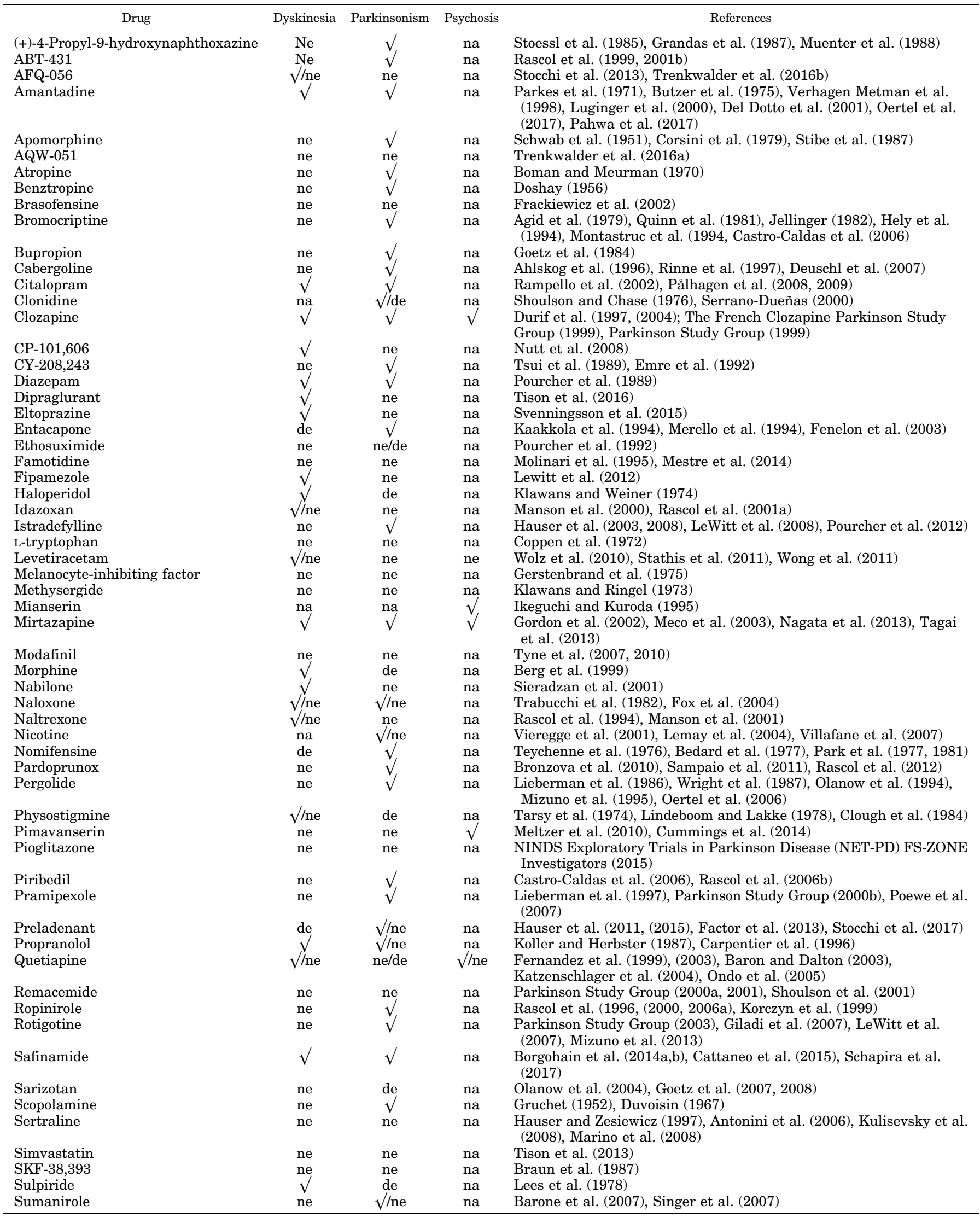


TABLE 4-Continued

\begin{tabular}{lcccl}
\hline & Drug & Dyskinesia & Parkinsonism & Psychosis \\
\hline Terguride & ne & $\sqrt{ }$ & na & Filipova et al. (1988), Martignoni et al. (1995) \\
Topiramate & ne/de & ne & na & Kobylecki et al. (2014), Goetz et al. (2017) \\
Trihexyphenidyl & ne & $\sqrt{ }$ & na & Martin et al. (1974), Lamid and Jenkins (1975) \\
Yohimbine & ne & $\sqrt{ }$ & na & Montastruc et al. (1981) \\
\hline
\end{tabular}

de, deleterious; na, not assessed; ne, not effective; $\sqrt{ }$, effective.

found with eight (44.4\% false-positive rate, Fig. 8). Of the five drugs that had a deleterious effect on parkinsonian disability, four were tested in the macaque, and this deleterious effect on parkinsonism was correctly identified in three ( $75 \%$ predictive value, Fig. 9).

MPTP-Lesioned Marmoset. Of the 34 drugs that showed antiparkinsonian effect in clinical trials, 23 were tested in the marmoset; an antiparkinsonian effect was obtained with 20 (86.9\% positive predictive value, Fig. 6 ). Of these, 24 drugs did not find or did not report an antiparkinsonian effect, 12 were tested in the marmoset, and no antiparkinsonian effect was encountered with six $(50.0 \%$ negative predictive value, Fig. 7), whereas antiparkinsonian benefit was found with five ( $41.7 \%$ false-positive rate, Fig. 8 ). Of the five drugs found to have a deleterious effect on parkinsonian disability, three were tested in the marmoset, all of which hindered parkinsonism (100\% predictive value, Fig. 9).

\section{Prediction of Antipsychotic Action}

Of the 64 drugs that were tested in the clinic and in the MPTP-lesioned primate, five showed an antipsychotic effect in clinical trials/reports (clozapine, mianserin, mirtazapine, pimavanserin, quetiapine). Compared with dyskinesia and parkinsonism, the effect of experimental drugs on dopaminergic psychosis has been far less studied in the MPTP-lesioned

anti-dyskinetic positive predictive value of the MPTPlesioned non-human primate

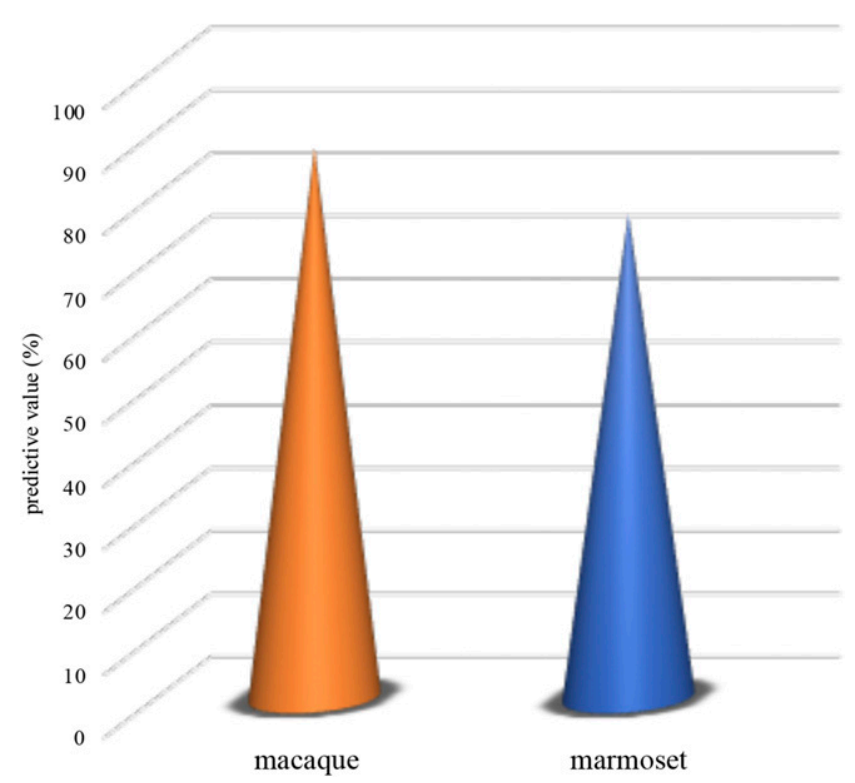

Fig. 3. The antidyskinetic positive predictive value of the MPTP-lesioned macaque is $87.5 \%$ and $76.9 \%$ for the MPTP-lesioned marmoset. primate. No drug that underwent clinical testing or that is clinically available has demonstrated antipsychotic effect in the MPTP-lesioned macaque or the MPTP-lesioned squirrel monkey. Pimavanserin was not tested in the MPTP-lesioned marmoset, but an antipsychotic benefit was achieved with clozapine, mianserin, mirtazapine, and quetiapine (100\% positive predictive value).

\section{Discussion}

Here, we have reviewed all the literature published in peerreviewed scientific journals that reported the results of pharmacologic studies conducted in the MPTP-lesioned macaque, marmoset, and squirrel monkey in which the effects of experimental drugs on dyskinesia, parkinsonism, and psychosis was assessed. By comparing the results obtained at the preclinical level with those obtained in clinical settings, we have calculated the predictive value of each primate species for these disease manifestations/treatment-related complications.

There are limitations to our analysis that must be mentioned. First, as mentioned in the Introduction, the results of several studies, both preclinical and clinical, have not been published; and, although we aimed for exhaustiveness, our review is necessarily incomplete, which may have affected the

anti-dyskinetic negative predictive value of the MPTPlesioned non-human primate

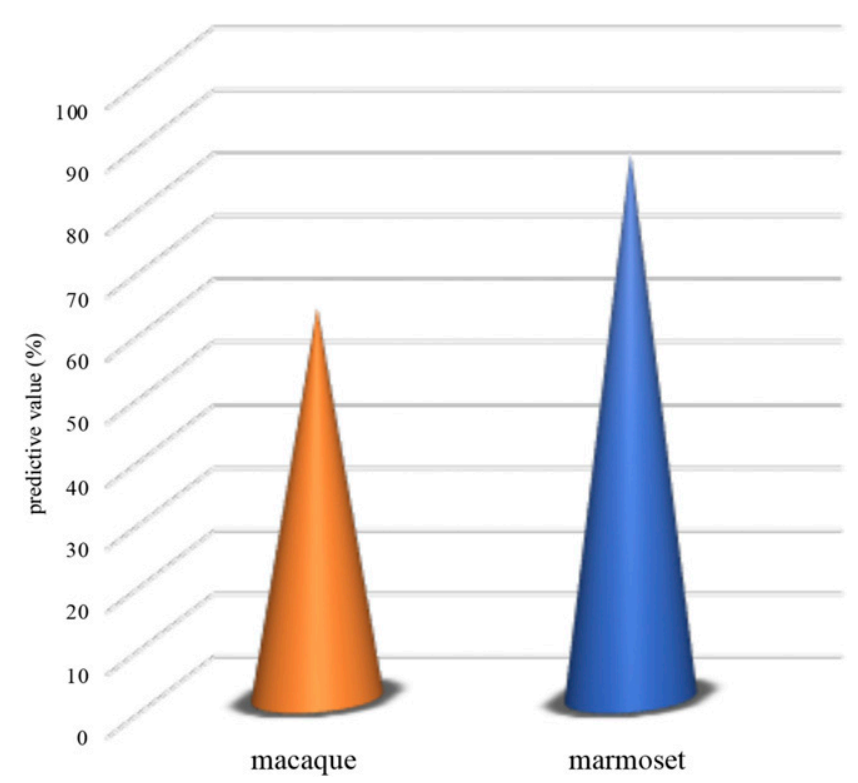

Fig. 4. The antidyskinetic negative predictive value of the MPTPlesioned macaque is $61.9 \%$ and $86.4 \%$ for the MPTP-lesioned marmoset. 
anti-dyskinetic false positive rate of the MPTP-lesioned non-human primate

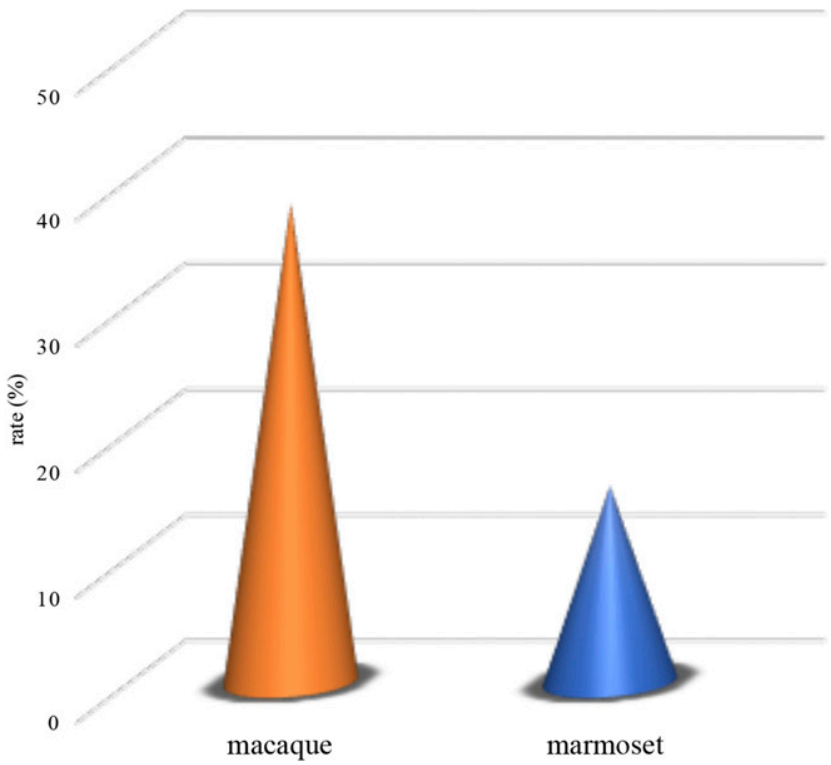

Fig. 5. The antidyskinetic false-positive rate of the MPTP-lesioned macaque is $38.1 \%$ and $15.6 \%$ for the MPTP-lesioned marmoset.

various rates presented. Second, the methods of the clinical trials cited is highly variable, ranging from observational reports to randomized controlled trials; they were weighed equally here. Third, the method used in preclinical studies is, at times, different from the one used in clinical settings; one example is when a low dose of L-DOPA is administered to primates in combination with an agent with potential antiparkinsonian effect as adjunct therapy. Lowering the L-DOPA

anti-parkinsonian positive predictive value of the MPTPlesioned non-human primate

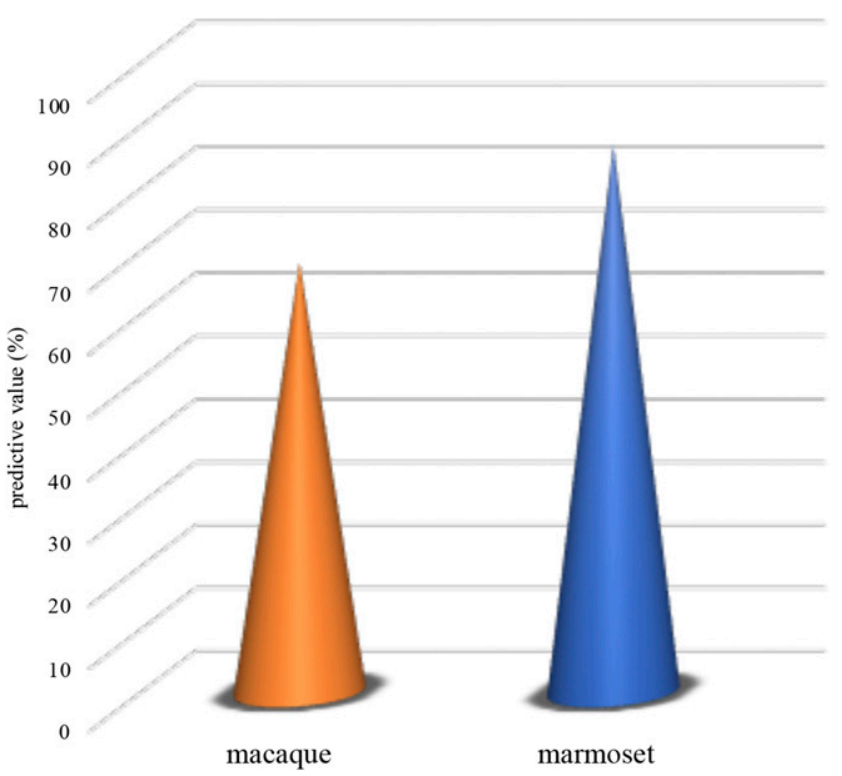

Fig. 6. The antiparkinsonian positive predictive value of the MPTPlesioned macaque is $68.2 \%$ and $86.9 \%$ for the MPTP-lesioned marmoset. anti-parkinsonian negative predictive value of the MPTPlesioned non-human primate

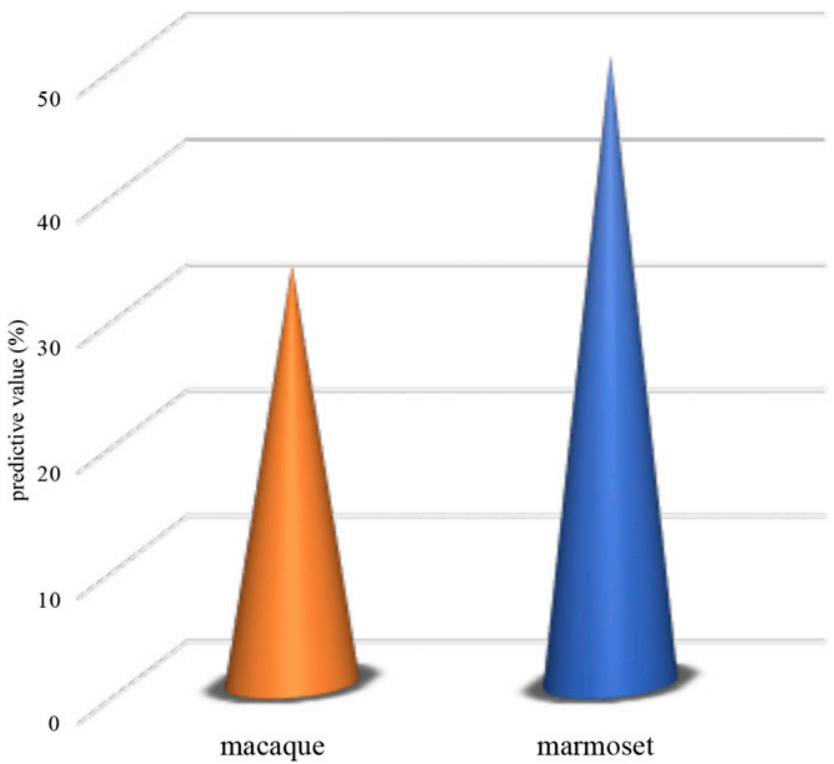

Fig. 7. The antiparkinsonian negative predictive value of the MPTPlesioned macaque is $33.3 \%$ and $50.0 \%$ for the MPTP-lesioned marmoset.

dose administered may be poorly tolerated by patients, which is why this approach is seldom used in clinical trials. Fourth, some clinical trials were performed in early stage PD patients, whereas the degree of parkinsonism after MPTP administration is severe and would correspond to advanced-stage PD. Finally, as several types of trials are part of our review, in some, PD patients were taking antiparkinsonian medication, in addition to L-DOPA, which is generally not the case in

anti-parkinsonian false positive rate of the MPTP-lesioned non-human primate

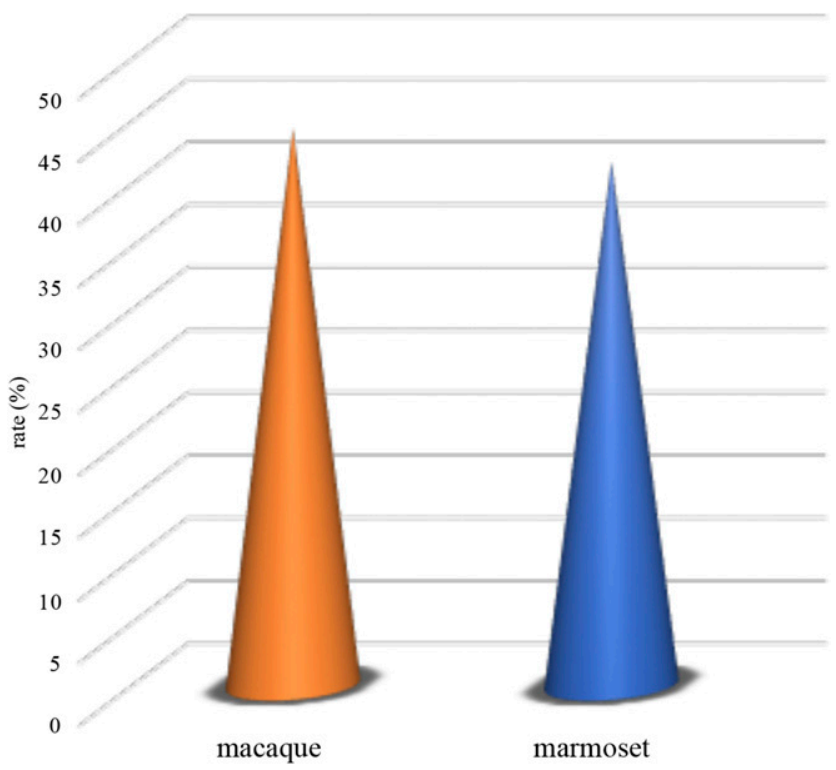

Fig. 8. The antiparkinsonian false-positive rate of the MPTP-lesioned macaque is $44.4 \%$ and $41.7 \%$ for the MPTP-lesioned marmoset. 
worsening of parkinsonism positive predictive value of the MPTP-lesioned non-human primate

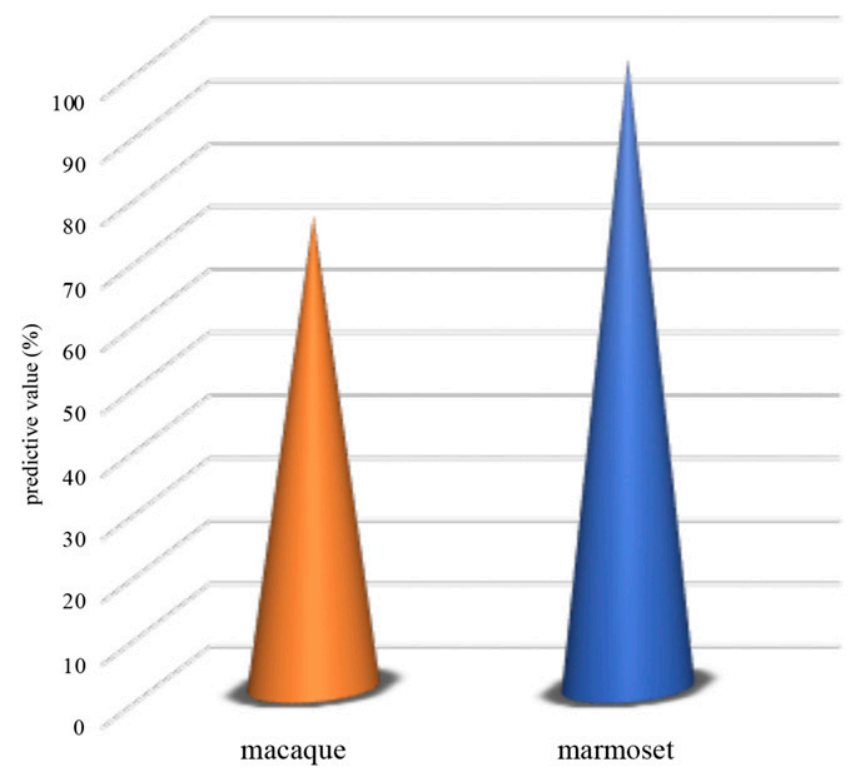

Fig. 9. The worsening of parkinsonism positive predictive value of the MPTP-lesioned macaque is $75.0 \%$ and $100.0 \%$ for the MPTP-lesioned marmoset.

primate studies, and the extent to which these molecules affected the results is undetermined.

Keeping these limitations in mind, the following general conclusions can be drawn:

- Relative to the antidyskinetic effect of drugs, the macaque has higher positive predictive value than the marmoset, but the marmoset has fewer false-positive results than the macaque. Both the macaque and the marmoset appear limited when it comes to predicting a detrimental effect of experimental drugs on dyskinesia.

- Relative to the antiparkinsonian action of drugs, the marmoset has a greater positive predictive value and fewer false-positive results than the macaque; both species have high predictive values when it comes to forecasting a potentially deleterious effect of drugs on parkinsonism.

- Relatively to the antipsychotic effect of drugs, comments can be made only for the marmoset, which has high positive predictive value.

- Compared with the macaque and the marmoset, the squirrel monkey has been used in a small number of studies, and few pharmacologic targets have been assessed in this primate species, which makes it impossible to calculate its predictive value.

At a time when the discovery and development process for drugs acting at the central nervous system level are facing challenges and have been marred by failures of high-profile candidates, it is our hope that this review will help in the planning and design of preclinical experiments aimed at testing the effects of drugs on L-DOPA-induced dyskinesia, parkinsonian disability, and dopaminergic psychosis by helping experimenters and sponsors plan their experiments in the animal model of PD with the highest translational potential for their specific endpoint.

\section{Authorship Contributions}

Participated in research design: Veyres, Huot.

Performed data analysis: Veyres, Huot.

Wrote or contributed to the writing of the manuscript: Veyres, Hamadjida, Huot.

\section{References}

Gad SC, editor (2009) Clinical Trials Handbook [Internet]. Wiley, Hoboken.

Agid Y, Pollak P, Bonnet AM, Signoret JL, and Lhermitte F (1979) Bromocriptine associated with a peripheral dopamine blocking agent in treatment of Parkinson's disease. Lancet 1:570-572.

Ahlskog JE, Wright KF, Muenter MD, and Adler CH (1996) Adjunctive cabergoline therapy of Parkinson's disease: comparison with placebo and assessment of dose responses and duration of effect. Clin Neuropharmacol 19:202-212.

Akai T, Ozawa M, Yamaguchi M, Mizuta E, and Kuno S (1995) Behavioral involvement of central dopamine D1 and D2 receptors in 1-methyl-4-phenyl-1,2,3,6tetrahydropyridine (MPTP)-lesioned parkinsonian cynomolgus monkeys. Jpn $J$ Pharmacol 67:117-124.

Antonini A, Tesei S, Zecchinelli A, Barone P, De Gaspari D, Canesi M, Sacilotto G, Meucci N, Mariani C, and Pezzoli G (2006) Randomized study of sertraline and low-dose amitriptyline in patients with Parkinson's disease and depression: effect on quality of life. Mov Disord 21:1119-1122.

Baron MS and Dalton WB (2003) Quetiapine as treatment for dopaminergic-induced dyskinesias in Parkinson's disease. Mov Disord 18:1208-1209.

Barone P, Lamb J, Ellis A, and Clarke Z (2007) Sumanirole versus placebo or ropinirole for the adjunctive treatment of patients with advanced Parkinson's disease. Mov Disord 22:483-489.

Bedard P, Parkes JD, and Marsden CD (1977) Nomifensine in Parkinson's disease. Br J Clin Pharmacol (4 Suppl 2)187S-190S.

Bédard PJ and Boucher R (1989) Effect of D1 receptor stimulation in normal and MPTP monkeys. Neurosci Lett 104:223-228.

Bédard PJ, Di Paolo T, Falardeau P, and Boucher R (1986) Chronic treatment with L-DOPA, but not bromocriptine induces dyskinesia in MPTP-parkinsonian monkeys. Correlation with [3H] spiperone binding. Brain Res 379:294-299.

Bélanger N, Grégoire L, Bédard P, and Di Paolo T (2003a) Estradiol and dehydroepiandrosterone potentiate levodopa-induced locomotor activity in 1-methyl-4phenyl-1,2,3,6-tetrahydropyridine monkeys. Endocrine 21:97-101.

Bélanger N, Grégoire L, Bédard PJ, and Di Paolo T (2006) DHEA improves symptomatic treatment of moderately and severely impaired MPTP monkeys. Neurobiol Aging 27:1684-1693.

Bélanger N, Grégoire L, Hadj Tahar A, and Bédard PJ (2003b) Chronic treatment with small doses of cabergoline prevents dopa-induced dyskinesias in parkinsonian monkeys. Mov Disord 18:1436-1441.

Belluzzi JD, Domino EF, May JM, Bankiewicz KS, and McAfee DA (1994) N-0923, a selective dopamine D2 receptor agonist, is efficacious in rat and monkey models of Parkinson's disease. Mov Disord 9:147-154.

Berg D, Becker G, and Reiners K (1999) Reduction of dyskinesia and induction of akinesia induced by morphine in two parkinsonian patients with severe sciatica. $J$ Neural Transm (Vienna) 106:725-728.

Bespalov A, Steckler T, Altevogt B, Koustova E, Skolnick P, Deaver D, Millan MJ, Bastlund JF, Doller D, Witkin J, et al. (2016) Failed trials for central nervous system disorders do not necessarily invalidate preclinical models and drug targets. Nat Rev Drug Discov 15:516.

Bezard E, Brefel C, Tison F, Peyro-Saint-Paul H, Ladure P, Rascol O, and Gross CE (1999) Effect of the alpha 2 adrenoreceptor antagonist, idazoxan, on motor disabilities in MPTP-treated monkey. Prog Neuropsychopharmacol Biol Psychiatry 23:1237-1246.

Bézard E, Ferry S, Mach U, Stark H, Leriche L, Boraud T, Gross C, and Sokoloff P (2003) Attenuation of levodopa-induced dyskinesia by normalizing dopamine D3 receptor function. Nat Med 9:762-767.

Bezard E, Hill MP, Crossman AR, Brotchie JM, Michel A, Grimée R, and Klitgaard H (2004) Levetiracetam improves choreic levodopa-induced dyskinesia in the MPTPtreated macaque. Eur J Pharmacol 485:159-164.

Bézard E, Muñoz A, Tronci E, Pioli EY, Li Q, Porras G, Björklund A, and Carta M (2013a) Anti-dyskinetic effect of anpirtoline in animal models of L-DOPA-induced dyskinesia. Neurosci Res 77:242-246.

Bezard E, Pioli EY, Li Q, Girard F, Mutel V, Keywood C, Tison F, Rascol O, and Poli SM (2014) The mGluR5 negative allosteric modulator dipraglurant reduces dyskinesia in the MPTP macaque model. Mov Disord 29:1074-1079.

Bezard E, Tronci E, Pioli EY, Li Q, Porras G, Björklund A, and Carta M (2013b) Study of the antidyskinetic effect of eltoprazine in animal models of levodopainduced dyskinesia. Mov Disord 28:1088-1096.

Bibbiani F, Costantini LC, Patel R, and Chase TN (2005a) Continuous dopaminergic stimulation reduces risk of motor complications in parkinsonian primates. Exp Neurol 192:73-78.

Bibbiani F, Oh JD, and Chase TN (2001) Serotonin 5-HT1A agonist improves motor complications in rodent and primate parkinsonian models. Neurology 57: 1829-1834.

Bibbiani F, Oh JD, Kielaite A, Collins MA, Smith C, and Chase TN (2005b) Combined blockade of AMPA and NMDA glutamate receptors reduces levodopa-induced motor complications in animal models of PD. Exp Neurol 196:422-429.

Bibbiani F, Oh JD, Petzer JP, Castagnoli N, Jr, Chen JF, Schwarzschild MA, and Chase TN (2003) A2A antagonist prevents dopamine agonist-induced motor complications in animal models of Parkinson's disease. Exp Neurol 184:285-294.

Blanchet P, Bédard PJ, Britton DR, and Kebabian JW (1993) Differential effect of selective D-1 and D-2 dopamine receptor agonists on levodopa-induced dyskinesia in 1-methyl-4-phenyl-1,2,3,6-tetrahydropyridine- exposed monkeys. J Pharmacol Exp Ther 267:275-279. 
Blanchet PJ, Boucher R, and Bédard PJ (1994) Excitotoxic lateral pallidotomy does not relieve L-dopa-induced dyskinesia in MPTP parkinsonian monkeys. Brain Res 650:32-39.

Blanchet PJ, Calon F, Martel JC, Bédard PJ, Di Paolo T, Walters RR, and Piercey MF (1995) Continuous administration decreases and pulsatile administration in creases behavioral sensitivity to a novel dopamine D2 agonist (U-91356A) in MPTP-exposed monkeys. $J$ Pharmacol Exp Ther 272:854-859.

Blanchet PJ, Grondin R, and Bédard PJ (1996a) Dyskinesia and wearing-off following dopamine D1 agonist treatment in drug-naive 1-methyl-4-phenyl-1,2,3,6 tetrahydropyridine-lesioned primates. Mov Disord 11:91-94.

Blanchet PJ, Grondin R, Bédard PJ, Shiosaki K, and Britton DR (1996b) Dopamine D1 receptor desensitization profile in MPTP-lesioned primates. Eur J Pharmacol 309:13-20.

Blanchet PJ, Konitsiotis S, and Chase TN (1997) Motor response to a dopamine D3 receptor preferring agonist compared to apomorphine in levodopa-primed 1-methyl-4-phenyl-1,2,3,6-tetrahydropyridine monkeys. J Pharmacol Exp Ther 283:794-799.

Blanchet PJ, Konitsiotis S, and Chase TN (1998) Amantadine reduces levodopainduced dyskinesias in parkinsonian monkeys. Mov Disord 13:798-802.

Blanchet PJ, Konitsiotis S, Whittemore ER, Zhou ZL, Woodward RM, and Chase TN (1999) Differing effects of N-methyl-D-aspartate receptor subtype selective antagonists on dyskinesias in levodopa-treated 1-methyl-4-phenyl-tetrahydropyridine monkeys. J Pharmacol Exp Ther 290:1034-1040.

Boman K and Meurman T (1970) Investigations on the effect of some drugs on the Parkinsonian rigidity. Acta Neurol Scand 46:71-84.

Borgohain R, Szasz J, Stanzione P, Meshram C, Bhatt M, Chirilineau D, Stocchi F, Lucini V, Giuliani R, Forrest E, et al.; Study 016 Investigators (2014a) Randomized trial of safinamide add-on to levodopa in Parkinson's disease with motor fluctuations. Mov Disord 29:229-237.

Borgohain R, Szasz J, Stanzione P, Meshram C, Bhatt MH, Chirilineau D, Stocchi F, Lucini V, Giuliani R, Forrest E, et al.; Study 018 Investigators (2014b) Two-year, randomized, controlled study of safinamide as add-on to levodopa in mid to late Parkinson's disease. Mov Disord 29:1273-1280.

Braun A, Fabbrini G, Mouradian MM, Serrati C, Barone P, and Chase TN (1987) Selective D-1 dopamine receptor agonist treatment of Parkinson's disease. $J$ Neural Transm (Vienna) 68:41-50.

Bronzova J, Sampaio C, Hauser RA, Lang AE, Rascol O, Theeuwes A, van de Witte SV, and van Scharrenburg G; Bruegel Study Group (2010) Double-blind study of pardoprunox, a new partial dopamine agonist, in early Parkinson's disease. Mov Disord 25:738-746.

Burns RS, Chiueh CC, Markey SP, Ebert MH, Jacobowitz DM, and Kopin IJ (1983) A primate model of parkinsonism: selective destruction of dopaminergic neurons in the pars compacta of the substantia nigra by N-methyl-4-phenyl-1,2,3,6-tetrahydropyridine. Proc Natl Acad Sci USA 80:4546-4550.

Butzer JF, Silver DE, and Sahs AL (1975) Amantadine in Parkinson's disease. A double-blind, placebo-controlled, crossover study with long-term follow-up. Neurology 25:603-606.

Calon F, Goulet M, Blanchet PJ, Martel JC, Piercey MF, Bédard PJ, and Di Paolo T (1995) Levodopa or D2 agonist induced dyskinesia in MPTP monkeys: correlation with changes in dopamine and GABAA receptors in the striatopallidal complex. Brain Res 680:43-52.

Calon F, Morissette M, Ghribi O, Goulet M, Grondin R, Blanchet PJ, Bédard PJ, and Di Paolo T (2002) Alteration of glutamate receptors in the striatum of dyskinetic 1-methyl-4-phenyl-1,2,3,6-tetrahydropyridine-treated monkeys following dopamine agonist treatment. Prog Neuropsychopharmacol Biol Psychiatry 26 $127-138$

Calon F, Morissette M, Goulet M, Grondin R, Blanchet PJ, Bédard PJ, and Di Paolo T (1999) Chronic D1 and D2 dopaminomimetic treatment of MPTP-denervated monkeys: effects on basal ganglia GABA(A)/benzodiazepine receptor complex and GABA content. Neurochem Int 35:81-91.

Calon F, Morissette M, Goulet M, Grondin R, Blanchet PJ, Bédard PJ, and Di Paolo T (2000) 125I-CGP 64213 binding to GABA(B) receptors in the brain of monkeys: effect of MPTP and dopaminomimetic treatments. Exp Neurol 163:191-199.

Cao X, Liang L, Hadcock JR, Iredale PA, Griffith DA, Menniti FS, Factor S, Greenamyre JT, and Papa SM (2007) Blockade of cannabinoid type 1 receptors augments the antiparkinsonian action of levodopa without affecting dyskinesias in 1-methyl-4-phenyl-1,2,3,6-tetrahydropyridine-treated rhesus monkeys. J Pharmacol Exp Ther 323:318-326.

Carpentier AF, Bonnet AM, Vidailhet M, and Agid Y (1996) Improvement of levodopa-induced dyskinesia by propranolol in Parkinson's disease. Neurology 46 : 1548-1551.

Castro-Caldas A, Delwaide P, Jost W, Merello M, Williams A, Lamberti P, Aguilar M, Del Signore S, and Cesaro P; Parkinson-Control Study Group (2006) The Parkinson-control study: a 1-year randomized, double-blind trial comparing piribedil $(150 \mathrm{mg} /$ day $)$ with bromocriptine $(25 \mathrm{mg} /$ day $)$ in early combination with levodopa in Parkinson's disease. Mov Disord 21:500-509.

Cattaneo C, Ferla RL, Bonizzoni E, and Sardina M (2015) Long-term effects of safinamide on dyskinesia in mid- to late-stage Parkinson's disease: a post-hoc analysis. J Parkinsons Dis 5:475-481.

Close SP, Elliott PJ, Hayes AG, and Marriott AS (1990) Effects of classical and novel agents in a MPTP-induced reversible model of Parkinson's disease. Psychopharmacology (Berl) 102:295-300.

Clough CG, Bergmann KJ, and Yahr MD (1984) Cholinergic and dopaminergic mechanisms in Parkinson's disease after long-term L-DOPA administration. Adv Neurol 40:131-140.

Cook D, Brown D, Alexander R, March R, Morgan P, Satterthwaite G, and Pangalos MN (2014) Lessons learned from the fate of AstraZeneca's drug pipeline: a fivedimensional framework. Nat Rev Drug Discov 13:419-431.

Coppen A, Metcalfe M, Carroll JD, and Morris JG (1972) Levodopa and L-tryptophan therapy in Parkinsonism. Lancet 1:654-658.
Corsini GU, Del Zompo M, Gessa GL, and Mangoni A (1979) Therapeutic efficacy of apomorphine combined with an extracerebral inhibitor of dopamine receptors in Parkinson's disease. Lancet 1:954-956.

Cox H, Togasaki DM, Chen L, Langston JW, Di Monte DA, and Quik M (2007) The selective kappa-opioid receptor agonist U50,488 reduces L-dopa-induced dyskinesias but worsens parkinsonism in MPTP-treated primates. Exp Neurol 205: 101-107.

Cummings J, Isaacson S, Mills R, Williams H, Chi-Burris K, Corbett A, Dhall R, and Ballard C (2014) Pimavanserin for patients with Parkinson's disease psychosis: a randomised, placebo-controlled phase 3 trial. Lancet 383:533-540.

Davis GC, Williams AC, Markey SP, Ebert MH, Caine ED, Reichert CM, and Kopin IJ (1979) Chronic Parkinsonism secondary to intravenous injection of meperidine analogues. Psychiatry Res 1:249-254.

Del Dotto P, Pavese N, Gambaccini G, Bernardini S, Metman LV, Chase TN, and Bonuccelli U (2001) Intravenous amantadine improves levadopa-induced dyskinesias: an acute double-blind placebo-controlled study. Mov Disord 16:515-520.

Deuschl G, Vaitkus A, Fox GC, Roscher T, Schremmer D, and Gordin A; CAMP Study Group (2007) Efficacy and tolerability of entacapone versus cabergoline in parkinsonian patients suffering from wearing-off. Mov Disord 22:1550-1555.

Di Paolo T, Bédard P, Daigle M, and Boucher R (1986) Long-term effects of MPTP on central and peripheral catecholamine and indoleamine concentrations in monkeys. Brain Res 379:286-293.

Di Paolo T, Grégoire L, Feuerbach D, Elbast W, Weiss M, and Gomez-Mancilla B (2014) AQW051, a novel and selective nicotinic acetylcholine receptor $\alpha 7$ partial agonist, reduces l-Dopa-induced dyskinesias and extends the duration of l-Dopa effects in parkinsonian monkeys. Parkinsonism Relat Disord 20:1119-1123.

Doan VD, Grondin R, Hadj Tahar A, Grégoire L, and Bédard PJ (1999) Effect of the selective D1 antagonists SCH 23390 and NNC 01-0112 on the delay, duration, and improvement of behavioral responses to dopaminergic agents in MPTP-treated monkeys. Clin Neuropharmacol 22:281-287.

Domino EF and Ni L (1998a) Trihexyphenidyl interactions with the dopamine D1selective receptor agonist SKF-82958 and the D2-selective receptor agonist N-0923 in 1-methyl-4-phenyl-1,2,3,6-tetrahydropyridine-induced hemiparkinsonian monkeys. J Pharmacol Exp Ther 284:307-311.

Domino EF and Ni L (1998b) Trihexyphenidyl potentiation of L-DOPA: reduced effectiveness three years later in MPTP-induced chronic hemiparkinsonian monkeys. Exp Neurol 152:238-242.

Doshay LJ (1956) Five-year study of benztropine (cogentin) methanesulfonate; outcome in three hundred two cases of paralysis agitans. J Am Med Assoc 162: 1031-1034

Durif F, Debilly B, Galitzky M, Morand D, Viallet F, Borg M, Thobois S, Broussolle E, and Rascol O (2004) Clozapine improves dyskinesias in Parkinson disease: a double-blind, placebo-controlled study. Neurology 62:381-388.

Durif F, Vidailhet M, Assal F, Roche C, Bonnet AM, and Agid Y (1997) Low-dose clozapine improves dyskinesias in Parkinson's disease. Neurology 48:658-662.

Duvoisin RC (1967) Cholinergic-anticholinergic antagonism in parkinsonism. Arch Neurol 17:124-136.

Ekesbo A, Andrén PE, Gunne LM, and Tedroff J (1997) (-)-OSU 6162 inhibits levodopa-induced dyskinesias in a monkey model of Parkinson's disease. Neuroreport 8:2567-2570.

Emre M, Rinne UK, Rascol A, Lees A, Agid Y, and Lataste X (1992) Effects of a selective partial D1 agonist, CY 208-243, in de novo patients with Parkinson disease. Mov Disord 7:239-243.

Factor SA, Wolski K, Togasaki DM, Huyck S, Cantillon M, Ho TW, Hauser RA, and Pourcher E (2013) Long-term safety and efficacy of preladenant in subjects with fluctuating Parkinson's disease. Mov Disord 28:817-820.

Falardeau P, Bouchard S, Bédard PJ, Boucher R, and Di Paolo T (1988) Behavioral and biochemical effect of chronic treatment with D-1 and/or D-2 dopamine agonists in MPTP monkeys. Eur J Pharmacol 150:59-66.

Fénelon G, Giménez-Roldán S, Montastruc JL, Bermejo F, Durif F, Bourdeix I, Péré JJ, Galiano L, and Schadrack J (2003) Efficacy and tolerability of entacapone in patients with Parkinson's disease treated with levodopa plus a dopamine agonist and experiencing wearing-off motor fluctuations. A randomized, double-blind, multicentre study. J Neural Transm (Vienna) 110:239-251.

Fernandez HH, Friedman JH, Jacques C, and Rosenfeld M (1999) Quetiapine for the treatment of drug-induced psychosis in Parkinson's disease. Mov Disord 14: $484-487$.

Fernandez HH, Trieschmann ME, Burke MA, Jacques C, and Friedman JH (2003) Long-term outcome of quetiapine use for psychosis among Parkinsonian patients. Mov Disord 18:510-514.

Fidalgo C, Ko WK, Tronci E, Li Q, Stancampiano R, Chuan Q, Bezard E, and Carta M (2015) Effect of serotonin transporter blockade on L-DOPA-induced dyskinesia in animal models of Parkinson's disease. Neuroscience 298:389-396.

Filion M, Tremblay L, and Bédard PJ (1991) Effects of dopamine agonists on the spontaneous activity of globus pallidus neurons in monkeys with MPTP-induced parkinsonism. Brain Res 547:152-161.

Filipová M, Filip V, Macek Z, Müllerová S, Marková J, Kás S, Zizková B, Krivka J Votavová M, and Krejcová H (1988) Terguride in parkinsonism: a multicenter trial. Eur Arch Psychiatry Neurol Sci 237:298-303.

Fox S, Silverdale M, Kellett M, Davies R, Steiger M, Fletcher N, Crossman A, and Brotchie J (2004) Non-subtype-selective opioid receptor antagonism in treatment of levodopa-induced motor complications in Parkinson's disease. Mov Disord 19:554-560.

Fox SH, Henry B, Hill M, Crossman A, and Brotchie J (2002) Stimulation of cannabinoid receptors reduces levodopa-induced dyskinesia in the MPTP-lesioned nonhuman primate model of Parkinson's disease. Mov Disord 17:1180-1187.

Fox SH, Henry B, Hill MP, Peggs D, Crossman AR, and Brotchie JM (2001) Neural mechanisms underlying peak-dose dyskinesia induced by levodopa and apomorphine are distinct: evidence from the effects of the alpha(2) adrenoceptor antagonist idazoxan. Mov Disord 16:642-650. 
Fox SH, Lang AE, and Brotchie JM (2006a) Translation of nondopaminergic treatments for levodopa-induced dyskinesia from MPTP-lesioned nonhuman primates to phase IIa clinical studies: keys to success and roads to failure. Mov Disord 21 : 1578-1594.

Fox SH, Visanji NP, Johnston TH, Gomez-Ramirez J, Voon V, and Brotchie JM (2006b) Dopamine receptor agonists and levodopa and inducing psychosis-like behavior in the MPTP primate model of Parkinson disease. Arch Neurol 63: 1343-1344

Frackiewicz EJ, Jhee SS, Shiovitz TM, Webster J, Topham C, Dockens RC, Whigan D, Salazar DE, and Cutler NR (2002) Brasofensine treatment for Parkinson's disease in combination with levodopa/carbidopa. Ann Pharmacother 36:225-230.

The French Clozapine Parkinson Study Group (1999) Clozapine in drug-induced psychosis in Parkinson's disease. Lancet 353:2041-2042.

Gagnon C, Bédard PJ, and Di Paolo T (1990) Effect of chronic treatment of MPTP monkeys with dopamine D-1 and/or D-2 receptor agonists. Eur J Pharmacol 178: $115-120$.

Gagnon C, Gomez-Mancilla B, Bédard PJ, and Di Paolo T (1993) Chronic CY 208-243 treatment of MPTP-monkeys causes regional changes of dopamine and GABAA receptors. Neurosci Lett 163:31-35.

Gagnon C, Gomez-Mancilla B, Markstein R, Bédard PJ, and Di Paolo T (1995) Effect of adding the D-1 agonist CY 208-243 to chronic bromocriptine treatment of MPTPmonkeys: regional changes of brain dopamine receptors. Prog Neuropsychopharmacol Biol Psychiatry 19:667-676.

Galvan A, Devergnas A, Pittard D, Masilamoni G, Vuong J, Daniels JS, Morrison RD, Lindsley CW, and Wichmann T (2016) Lack of antiparkinsonian effects of systemic injections of the specific T-type calcium channel blocker ML218 in MPTP-treated monkeys. ACS Chem Neurosci 7:1543-1551.

Gerstenbrand F, Binder H, Kozma C, Pusch ST, and Reisner Th (1975) Infusion therapy with mif (melanocyte inhibiting factor) in Parkinson's disease (author's transl). Wien Klin Wochenschr 87:822-823.

Giladi N, Boroojerdi B, Korczyn AD, Burn DJ, Clarke CE, and Schapira AH; SP513 investigators (2007) Rotigotine transdermal patch in early Parkinson's disease: a randomized, double-blind, controlled study versus placebo and ropinirole. Mov Disord 22:2398-2404.

Gnanalingham KK, Erol DD, Hunter AJ, Smith LA, Jenner P, and Marsden CD (1995a) Differential anti-parkinsonian effects of benzazepine D1 dopamine agonists with varying efficacies in the MPTP-treated common marmoset. Psychopharmacology (Berl) 117:275-286.

Gnanalingham KK, Hunter AJ, Jenner P, and Marsden CD (1995b) The differential behavioural effects of benzazepine D1 dopamine agonists with varying efficacies, co-administered with quinpirole in primate and rodent models of Parkinson's disease. Psychopharmacology (Berl) 117:287-297.

Gnanalingham KK, Hunter AJ, Jenner P, and Marsden CD (1995c) Selective dopamine antagonist pretreatment on the antiparkinsonian effects of benzazepine D1 dopamine agonists in rodent and primate models of Parkinson's disease-the differential effects of D1 dopamine antagonists in the primate. Psychopharmacology (Berl) 117:403-412.

Goetz CG, Damier P, Hicking C, Laska E, Müller T, Olanow CW, Rascol O, and Russ $\mathrm{H}$ (2007) Sarizotan as a treatment for dyskinesias in Parkinson's disease: a doubleblind placebo-controlled trial. Mov Disord 22:179-186.

Goetz CG, Laska E, Hicking C, Damier P, Müller T, Nutt J, Warren Olanow C, Rascol $\mathrm{O}$, and Russ H (2008) Placebo influences on dyskinesia in Parkinson's disease. Mov Disord 23:700-707.

Goetz CG, Stebbins GT, Chung KA, Nicholas AP, Hauser RA, Merkitch D, and Stacy MA (2017) Topiramate as an adjunct to amantadine in the treatment of dyskinesia in parkinson's disease: a randomized, double-blind, placebo-controlled multicenter study. Mov Disord 32:1335-1336.

Goetz CG, Tanner CM, and Klawans HL (1984) Bupropion in Parkinson's disease. Neurology 34:1092-1094.

Gomez-Mancilla B and Bédard PJ (1991) Effect of D1 and D2 agonists and antagonists on dyskinesia produced by L-dopa in 1-methyl-4-phenyl-1,2,3,6tetrahydropyridine-treated monkeys. J Pharmacol Exp Ther 259:409-413.

Gomez-Mancilla B and Bédard PJ (1992a) Effect of chronic treatment with (+)PHNO, a D2 agonist in MPTP-treated monkeys. Exp Neurol 117:185-188.

Gomez-Mancilla B and Bédard PJ (1992b) Effect of estrogen and progesterone on L-dopa induced dyskinesia in MPTP-treated monkeys. Neurosci Lett 135:129-132

Gomez-Mancilla B and Bédard PJ (1993) Effect of nondopaminergic drugs on L-dopainduced dyskinesias in MPTP-treated monkeys. Clin Neuropharmacol 16:418-427.

Gomez-Mancilla B, Boucher R, and Bédard PJ (1991) Effect of clonidine and atropine on rest tremor in the MPTP monkey model of parkinsonism. Clin Neuropharmacol 14:359-366.

Gomez-Mancilla B, Boucher R, and Bédard PJ (1992a) Effect of LY 171555 and CY 208-243 on tremor suppression in the MPTP monkey model of parkinsonism. Mov Disord 7:43-47.

Gomez-Mancilla B, Boucher R, Gagnon C, Di Paolo T, Markstein R, and Bédard PJ (1993) Effect of adding the D1 agonist CY 208-243 to chronic bromocriptine treatment. I: evaluation of motor parameters in relation to striatal catecholamine content and dopamine receptors. Mov Disord 8:144-150.

Gomez-Mancilla B, Latulippe JF, Boucher R, and Bédard PJ (1992b) Effect of ethosuximide on rest tremor in the MPTP monkey model. Mov Disord 7:137-141.

Gomez-Ramirez J, Johnston TH, Visanji NP, Fox SH, and Brotchie JM (2006) Histamine $\mathrm{H} 3$ receptor agonists reduce L-dopa-induced chorea, but not dystonia, in the MPTP-lesioned nonhuman primate model of Parkinson's disease. Mov Disord 21:839-846.

Gordon PH, Pullman SL, Louis ED, Frucht SJ, and Fahn S (2002) Mirtazapine in Parkinsonian tremor. Parkinsonism Relat Disord 9:125-126.

Goulet M, Grondin R, Blanchet PJ, Bédard PJ, and Di Paolo T (1996) Dyskinesias and tolerance induced by chronic treatment with a D1 agonist administered in pulsatile or continuous mode do not correlate with changes of putaminal D1 receptors in drug-naive MPTP monkeys. Brain Res 719:129-137.
Goulet M, Grondin R, Morissette M, Maltais S, Falardeau P, Bédard PJ, and Di Paolo $\mathrm{T}$ (2000) Regulation by chronic treatment with cabergoline of dopamine D1 and D2 receptor levels and their expression in the striatum of Parkinsonian-monkeys. Prog Neuropsychopharmacol Biol Psychiatry 24:607-617.

Goulet M, Morissette M, Calon F, Blanchet PJ, Falardeau P, Bédard PJ, and Di Paolo $\mathrm{T}$ (1997) Continuous or pulsatile chronic D2 dopamine receptor agonist (U91356A) treatment of drug-naive 4-phenyl-1,2,3,6-tetrahydropyridine monkeys differentially regulates brain D1 and D2 receptor expression: in situ hybridization histochemical analysis. Neuroscience 79:497-507.

Goulet M, Morissette M, Grondin R, Falardeau P, Bédard PJ, Rostène W, and Di Paolo T (1999) Neurotensin receptors and dopamine transporters: effects of MPTP lesioning and chronic dopaminergic treatments in monkeys. Synapse 32: $153-164$

Grandas F, Quinn N, Critchley P, Rohan A, Marsden CD, and Stahl SM (1987) Antiparkinsonian activity of a single oral dose of PHNO. Mov Disord 2:47-51.

Greenamyre JT, Eller RV, Zhang Z, Ovadia A, Kurlan R, and Gash DM (1994) Antiparkinsonian effects of remacemide hydrochloride, a glutamate antagonist, in rodent and primate models of Parkinson's disease. Ann Neurol 35:655-661.

Grégoire L, Jourdain VA, Townsend M, Roach A, and Di Paolo T (2013) Safinamide reduces dyskinesias and prolongs L-DOPA antiparkinsonian effect in parkinsonian monkeys. Parkinsonism Relat Disord 19:508-514.

Grégoire L, Morin N, Ouattara B, Gasparini F, Bilbe G, Johns D, Vranesic I, Sahasranaman S, Gomez-Mancilla B, and Di Paolo T (2011) The acute antiparkinsonian and antidyskinetic effect of AFQ056, a novel metabotropic glutamate receptor type 5 antagonist, in l-Dopa-treated parkinsonian monkeys. Parkinsonism Relat Disord 17:270-276

Grégoire L, Rassoulpour A, Guidetti P, Samadi P, Bédard PJ, Izzo E, Schwarcz R, and Di Paolo T (2008) Prolonged kynurenine 3-hydroxylase inhibition reduces development of levodopa-induced dyskinesias in parkinsonian monkeys. Behav Brain Res 186:161-167.

Grégoire L, Samadi P, Graham J, Bédard PJ, Bartoszyk GD, and Di Paolo T (2009) Low doses of sarizotan reduce dyskinesias and maintain antiparkinsonian efficacy of L-Dopa in parkinsonian monkeys. Parkinsonism Relat Disord 15:445-452.

Grégoire L, Smith T, Senanayake V, Mochizuki A, Miville-Godbout E, Goodenowe D, and Di Paolo T (2015) Plasmalogen precursor analog treatment reduces levodopainduced dyskinesias in parkinsonian monkeys. Behav Brain Res 286:328-337.

Grondin R, Bédard PJ, Britton DR, and Shiosaki K (1997) Potential therapeutic use of the selective dopamine D1 receptor agonist, A-86929: an acute study in parkinsonian levodopa-primed monkeys. Neurology 49:421-426.

Grondin R, Bédard PJ, Hadj Tahar A, Grégoire L, Mori A, and Kase H (1999a) Antiparkinsonian effect of a new selective adenosine A2A receptor antagonist in MPTP-treated monkeys. Neurology 52:1673-1677.

Grondin R, Doan VD, Grégoire L, and Bédard PJ (1999b) D1 receptor blockade improves L-dopa-induced dyskinesia but worsens parkinsonism in MPTP monkeys. Neurology 52:771-776.

Grondin R, Goulet M, Di Paolo T, and Bédard PJ (1996) Cabergoline, a long-acting dopamine D2-like receptor agonist, produces a sustained antiparkinsonian effect with transient dyskinesias in parkinsonian drug-naive primates. Brain Res $\mathbf{7 3 5}$ 298-306.

Grondin R, Goulet M, Morissette M, Bédard PJ, and Di Paolo T (1999c) Dopamine D1 receptor mRNA and receptor levels in the striatum of MPTP monkeys chronically treated with SKF-82958. Eur J Pharmacol 378:259-263.

Grondin R, Hadj Tahar A, Doan VD, Ladure P, and Bédard PJ (2000) Noradrenoceptor antagonism with idazoxan improves L-dopa-induced dyskinesias in MPTP monkeys. Naunyn Schmiedebergs Arch Pharmacol 361:181-186.

Gruchet R (1952) Scopolamine in parkinsonism. Therapie 7:114-121.

Hadj Tahar A, Bélanger N, Bangassoro E, Grégoire L, and Bédard PJ (2000a) Antidyskinetic effect of JL-18, a clozapine analog, in parkinsonian monkeys. Eur $J$ Pharmacol 399:183-186.

Hadj Tahar A, Ekesbo A, Grégoire L, Bangassoro E, Svensson KA, Tedroff J, and Bédard PJ (2001) Effects of acute and repeated treatment with a novel dopamine D2 receptor ligand on L-DOPA-induced dyskinesias in MPTP monkeys. Eur J Pharmacol 412:247-254.

Hadj Tahar A, Grégoire L, Bangassoro E, and Bédard PJ (2000b) Sustained cabergoline treatment reverses levodopa-induced dyskinesias in parkinsonian monkeys. Clin Neuropharmacol 23:195-202.

Hadj Tahar A, Grégoire L, Darré A, Bélanger N, Meltzer L, and Bédard PJ (2004) Effect of a selective glutamate antagonist on L-dopa-induced dyskinesias in drugnaive parkinsonian monkeys. Neurobiol Dis 15:171-176.

Hamadjida A, Nuara SG, Gourdon JC, and Huot P (2018) The effect of mianserin on the severity of psychosis and dyskinesia in the parkinsonian marmoset. Prog Neuropsychopharmacol Biol Psychiatry 81:367-371.

Hamadjida A, Nuara SG, Veyres N, Frouni I, Kwan C, Sid-Otmane L, Harraka MJ, Gourdon JC, and Huot P (2017) The effect of mirtazapine on dopaminergic psychosis and dyskinesia in the parkinsonian marmoset. Psychopharmacology (Berl) 234:905-911.

Hansard MJ, Jackson MJ, Smith LA, Rose S, and Jenner P (2011) A major metabolite of bupropion reverses motor deficits in 1-methyl-4-phenyl-1,2,3,6-tetrahydropyridinetreated common marmosets. Behav Pharmacol 22:269-274.

Hansard MJ, Smith LA, Jackson MJ, Cheetham SC, and Jenner P (2002a) Dopamine reuptake inhibition and failure to evoke dyskinesia in MPTP-treated primates. Eur $J$ Pharmacol 451:157-160.

Hansard MJ, Smith LA, Jackson MJ, Cheetham SC, and Jenner P (2002b) Dopamine, but not norepinephrine or serotonin, reuptake inhibition reverses motor deficits in 1-methyl-4-phenyl-1,2,3,6-tetrahydropyridine-treated primates. J Pharmacol Exp Ther 303:952-958

Hansard MJ, Smith LA, Jackson MJ, Cheetham SC, and Jenner P (2004) The monoamine reuptake inhibitor BTS 74398 fails to evoke established dyskinesia but does not synergise with levodopa in MPTP-treated primates. Mov Disord 19 15-21. 
Hauser RA, Cantillon M, Pourcher E, Micheli F, Mok V, Onofrj M, Huyck S, and Wolski K (2011) Preladenant in patients with Parkinson's disease and motor fluctuations: a phase 2, double-blind, randomised trial. Lancet Neurol 10 221-229.

Hauser RA, Hubble JP, and Truong DD; Istradefylline US-001 Study Group (2003) Randomized trial of the adenosine $\mathrm{A}(2 \mathrm{~A})$ receptor antagonist istradefylline in advanced PD. Neurology 61:297-303.

Hauser RA, Shulman LM, Trugman JM, Roberts JW, Mori A, Ballerini R, and Sussman NM; Istradefylline 6002-US-013 Study Group (2008) Study of istradefylline in patients with Parkinson's disease on levodopa with motor fluctuations. Mov Disord 23:2177-2185.

Hauser RA, Stocchi F, Rascol O, Huyck SB, Capece R, Ho TW, Sklar P, Lines C, Michelson D, and Hewitt D (2015) Preladenant as an adjunctive therapy with levodopa in Parkinson disease: two randomized clinical trials and lessons learned. JAMA Neurol 72:1491-1500.

Hauser RA and Zesiewicz TA (1997) Sertraline for the treatment of depression in Parkinson's disease. Mov Disord 12:756-759.

Hely MA, Morris JG, Reid WG, O'Sullivan DJ, Williamson PM, Rail D, Broe GA, and Margrie S (1994) The Sydney multicentre study of Parkinson's disease: a randomised, prospective five year study comparing low dose bromocriptine with low dose levodopa-carbidopa. J Neurol Neurosurg Psychiatry 57:903-910.

Henry B, Fox SH, Crossman AR, and Brotchie JM (2001) Mu- and delta-opioid receptor antagonists reduce levodopa-induced dyskinesia in the MPTP-lesioned primate model of Parkinson's disease. Exp Neurol 171:139-146.

Henry B, Fox SH, Peggs D, Crossman AR, and Brotchie JM (1999) The alpha2 adrenergic receptor antagonist idazoxan reduces dyskinesia and enhances antiparkinsonian actions of L-dopa in the MPTP-lesioned primate model of Parkinson's disease. Mov Disord 14:744-753.

Hill MP, Bezard E, McGuire SG, Crossman AR, Brotchie JM, Michel A, Grimée R, and Klitgaard $\mathrm{H}$ (2003) Novel antiepileptic drug levetiracetam decreases dyskinesia elicited by L-dopa and ropinirole in the MPTP-lesioned marmoset. Mov Disord 18:1301-1305.

Hill MP, Brotchie JM, Crossman AR, Bezard E, Michel A, Grimée R, and Klitgaard H (2004a) Levetiracetam interferes with the L-dopa priming process in MPTPlesioned drug-naive marmosets. Clin Neuropharmacol 27:171-177.

Hill MP, Ravenscroft P, Bezard E, Crossman AR, Brotchie JM, Michel A, Grimée R, and Klitgaard $\mathrm{H}(2004 \mathrm{~b})$ Levetiracetam potentiates the antidyskinetic action of amantadine in the 1-methyl-4-phenyl-1,2,3,6-tetrahydropyridine (MPTP)-lesioned primate model of Parkinson's disease. J Pharmacol Exp Ther 310:386-394.

Hill MP, Ravenscroft P, McGuire SG, Brotchie JM, Crossman AR, Rochat C, and Millan MJ (2006) Antiparkinsonian effects of the novel D3/D2 dopamine receptor agonist, S32504, in MPTP-lesioned marmosets: mediation by D2, not D3, dopamine receptors. Mov Disord 21:2090-2095.

Hille CJ, Fox SH, Maneuf YP, Crossman AR, and Brotchie JM (2001) Antiparkinsonian action of a delta opioid agonist in rodent and primate models of Parkinson's disease. Exp Neurol 172:189-198.

Hodgson RA, Bedard PJ, Varty GB, Kazdoba TM, Di Paolo T, Grzelak ME, Pond AJ, Hadjtahar A, Belanger N, Gregoire L, et al. (2010) Preladenant, a selective A(2A) receptor antagonist, is active in primate models of movement disorders. Exp Neurol 225:384-390.

Hsu A, Togasaki DM, Bezard E, Sokoloff P, Langston JW, Di Monte DA, and Quik M (2004) Effect of the D3 dopamine receptor partial agonist BP897 [N-[4-(4-(2 methoxyphenyl)piperazinyl)butyl]-2-naphthamide] on L-3,4-dihydroxyphenylalanineinduced dyskinesias and parkinsonism in squirrel monkeys. $J$ Pharmacol Exp Ther 311:770-777.

Huot P, Johnston TH, Fox SH, and Brotchie JM (2015a) Pioglitazone may impair L-DOPA anti-parkinsonian efficacy in the MPTP-lesioned macaque: results of a pilot study. Synapse 69:99-102.

Huot P, Johnston TH, Fox SH, Newman-Tancredi A, and Brotchie JM (2015b) The highly-selective 5-HT(1A) agonist F15599 reduces L-DOPA-induced dyskinesia without compromising anti-parkinsonian benefits in the MPTP-lesioned macaque. Neuropharmacology 97:306-311.

Huot P, Johnston TH, Gandy MN, Reyes MG, Fox SH, Piggott MJ, and Brotchie JM (2012a) The monoamine re-uptake inhibitor UWA-101 improves motor fluctuations in the MPTP-lesioned common marmoset. PLoS One 7:e45587.

Huot P, Johnston TH, Koprich JB, Aman A, Fox SH, and Brotchie JM (2012b) L745,870 reduces L-DOPA-induced dyskinesia in the 1-methyl-4-phenyl-1,2,3,6tetrahydropyridine-lesioned macaque model of Parkinson's disease. J Pharmaco Exp Ther 342:576-585.

Huot P, Johnston TH, Lewis KD, Koprich JB, Reyes MG, Fox SH, Piggott MJ, and Brotchie JM (2011) Characterization of 3,4-methylenedioxymethamphetamine (MDMA) enantiomers in vitro and in the MPTP-lesioned primate: R-MDMA reduces severity of dyskinesia, whereas S-MDMA extends duration of ON-time. $J$ Neurosci 31:7190-7198.

Huot P, Johnston TH, Lewis KD, Koprich JB, Reyes MG, Fox SH, Piggott MJ, and Brotchie JM (2014) UWA-121, a mixed dopamine and serotonin re-uptake inhibitor, enhances L-DOPA anti-parkinsonian action without worsening dyskinesia or psychosis-like behaviours in the MPTP-lesioned common marmoset. Neuropharmacology 82:76-87.

Huot P, Johnston TH, Snoeren T, Koprich JB, Hill MP, Fox SH, and Brotchie JM (2013) Use of catechol-O-methyltransferase inhibition to minimize L-3,4dihydroxyphenylalanine-induced dyskinesia in the 1-methyl-4-phenyl-1,2,3,6tetrahydropyridine-lesioned macaque. Eur J Neurosci 37:831-838.

Huot P, Lévesque M, Morissette M, Calon F, Dridi M, Di Paolo T, and Parent A (2008) L-Dopa treatment abolishes the numerical increase in striatal dopaminergic neurons in parkinsonian monkeys. $J$ Chem Neuroanat 35:77-84.

Hyacinthe C, Barraud Q, Tison F, Bezard E, and Ghorayeb I (2014) D1 receptor agonist improves sleep-wake parameters in experimental parkinsonism. Neurobiol Dis 63:20-24.
Ikeguchi K and Kuroda A (1995) Mianserin treatment of patients with psychosis induced by antiparkinsonian drugs. Eur Arch Psychiatry Clin Neurosci 244 $320-324$

Iravani MM, Jackson MJ, Kuoppamäki M, Smith LA, and Jenner P (2003) 3,4methylenedioxymethamphetamine (ecstasy) inhibits dyskinesia expression and normalizes motor activity in 1-methyl-4-phenyl-1,2,3,6-tetrahydropyridine-treated primates. J Neurosci 23:9107-9115.

Iravani MM, Tayarani-Binazir K, Chu WB, Jackson MJ, and Jenner P (2006) In 1-methyl-4-phenyl-1,2,3,6-tetrahydropyridine-treated primates, the selective 5-hydroxytryptamine 1a agonist (R)-(+)-8-OHDPAT inhibits levodopa-induced dyskinesia but only withincreased motor disability. J Pharmacol Exp Ther 319: $1225-1234$

Jackson MJ, Al-Barghouthy G, Pearce RK, Smith L, Hagan JJ, and Jenner P (2004) Effect of 5-HT1B/D receptor agonist and antagonist administration on motor function in haloperidol and MPTP-treated common marmosets. Pharmacol Biochem Behav 79:391-400.

Jackson MJ, Andree TH, Hansard M, Hoffman DC, Hurtt MR, Kehne JH, Pitler TA, Smith LA, Stack G, and Jenner P (2010) The dopamine D(2) receptor partial agonist aplindore improves motor deficits in MPTP-treated common marmosets alone and combined with L-dopa. J Neural Transm (Vienna) 117:55-67.

Jackson MJ, Smith LA, Al-Barghouthy G, Rose S, and Jenner P (2007) Decreased expression of l-dopa-induced dyskinesia by switching to ropinirole in MPTP-treated common marmosets. Exp Neurol 204:162-170.

Jackson MJ, Swart T, Pearce RK, and Jenner P (2014) Cholinergic manipulation of motor disability and L-DOPA-induced dyskinesia in 1-methyl-4-phenyl-1,2,3,6 tetrahydropyridine (MPTP)-treated common marmosets. J Neural Transm (Vienna) 121:163-169.

Jan C, François C, Tandé D, Yelnik J, Tremblay L, Agid Y, and Hirsch E (2000) Dopaminergic innervation of the pallidum in the normal state, in MPTP-treated monkeys and in parkinsonian patients. Eur $J$ Neurosci 12:4525-4535.

Jellinger K (1982) Adjuvant treatment of Parkinson's disease with dopamine agonists: open trial with bromocriptine and CU 32-085. J Neurol 227:75-88.

Jenner P, Rupniak NM, Rose S, Kelly E, Kilpatrick G, Lees A, and Marsden CD (1984) 1-Methyl-4-phenyl-1,2,3,6-tetrahydropyridine-induced parkinsonism in the common marmoset. Neurosci Lett 50:85-90.

Jenner P, Zeng BY, Smith LA, Pearce RK, Tel B, Chancharme L, and Moachon G (2000) Antiparkinsonian and neuroprotective effects of modafinil in the mptptreated common marmoset. Exp Brain Res 133:178-188.

Johnston LC, Jackson MJ, Rose S, McCreary AC, and Jenner P (2010a) Pardoprunox reverses motor deficits but induces only mild dyskinesia in MPTP-treated common marmosets. Mov Disord 25:2059-2066.

Johnston TH, Fox SH, McIldowie MJ, Piggott MJ, and Brotchie JM (2010b) Reduction of L-DOPA-induced dyskinesia by the selective metabotropic glutamate receptor 5 antagonist 3-[(2-methyl-1,3-thiazol-4-yl)ethynyl]pyridine in the 1-methyl-4-phenyl-1,2,3,6-tetrahydropyridine-lesioned macaque model of Parkin son's disease. J Pharmacol Exp Ther 333:865-873.

Johnston TH, Fox SH, Piggott MJ, Savola JM, and Brotchie JM (2010c) The $\alpha_{2}$ adrenergic antagonist fipamezole improves quality of levodopa action in Parkinsonian primates. Mov Disord 25:2084-2093.

Johnston TH, Huot P, Damude S, Fox SH, Jones SW, Rusche JR, and Brotchie JM (2013a) RGFP109, a histone deacetylase inhibitor attenuates L-DOPA-induced dyskinesia in the MPTP-lesioned marmoset: a proof-of-concept study. Parkinsonism Relat Disord 19:260-264

Johnston TH, Huot P, Fox SH, Koprich JB, Szeliga KT, James JW, Graef JD, Letchworth SR, Jordan KG, Hill MP, et al. (2013b) TC-8831, a nicotinic acetylcholine receptor agonist, reduces L-DOPA-induced dyskinesia in the MPTP macaque. Neuropharmacology 73:337-347.

Johnston TH, Huot P, Fox SH, Wakefield JD, Sykes KA, Bartolini WP, Milne GT, Pearson JP, and Brotchie JM (2011) Fatty acid amide hydrolase (FAAH) inhibition reduces L-3,4-dihydroxyphenylalanine-induced hyperactivity in the 1-methyl-4 phenyl-1,2,3,6-tetrahydropyridine-lesioned non-human primate model of Parkinson's disease. J Pharmacol Exp Ther 336:423-430.

Johnston TH, Millar Z, Huot P, Wagg K, Thiele S, Salomonczyk D, Yong-Kee CJ, Gandy MN, McIldowie M, Lewis KD, et al. (2012) A novel MDMA analogue, UWA101, that lacks psychoactivity and cytotoxicity, enhances L-DOPA benefit in parkinsonian primates. FASEB J 26:2154-2163.

Johnston TH, van der Meij A, Brotchie JM, and Fox SH (2010d) Effect of histamine $\mathrm{H} 2$ receptor antagonism on levodopa-induced dyskinesia in the MPTP-macaque model of Parkinson's disease. Mov Disord 25:1379-1390.

Jones CA, Johnston LC, Jackson MJ, Smith LA, van Scharrenburg G, Rose S, Jenner PG, and McCreary AC (2010) An in vivo pharmacological evaluation of pardoprunox (SLV308)-a novel combined dopamine $\mathrm{D}(2) / \mathrm{D}(3)$ receptor partial agonist and 5 -HT(1A) receptor agonist with efficacy in experimental models of Parkinson's disease. Eur Neuropsychopharmacol 20:582-593.

Kaakkola S, Teräväinen H, Ahtila S, Rita H, and Gordin A (1994) Effect of entacapone, a COMT inhibitor, on clinical disability and levodopa metabolism in parkinsonian patients. Neurology 44:77-80.

Kanda T, Jackson MJ, Smith LA, Pearce RK, Nakamura J, Kase H, Kuwana Y, and Jenner P (1998a) Adenosine A2A antagonist: a novel antiparkinsonian agent that does not provoke dyskinesia in parkinsonian monkeys. Ann Neurol 43: $507-513$.

Kanda T, Jackson MJ, Smith LA, Pearce RK, Nakamura J, Kase H, Kuwana Y, and Jenner P (2000) Combined use of the adenosine A(2A) antagonist KW-6002 with L-DOPA or with selective D1 or D2 dopamine agonists increases antiparkinsonian activity but not dyskinesia in MPTP-treated monkeys. Exp Neurol 162:321-327.

Kanda T, Tashiro T, Kuwana Y, and Jenner P (1998b) Adenosine A2A receptors modify motor function in MPTP-treated common marmosets. Neuroreport 9: $2857-2860$. 
Katzenschlager R, Jackson MJ, Rose S, Stockwell K, Tayarani-Binazir KA, Zubair M, Smith LA, Jenner P, and Lees AJ (2007) Antiparkinsonian activity of L-propyl-Lleucyl-glycinamide or melanocyte-inhibiting factor in MPTP-treated common marmosets. Mov Disord 22:715-719.

Katzenschlager R, Manson AJ, Evans A, Watt H, and Lees AJ (2004) Low dose quetiapine for drug induced dyskinesias in Parkinson's disease: a double blind cross over study. J Neurol Neurosurg Psychiatry 75:295-297.

Kebabian JW, Britton DR, DeNinno MP, Perner R, Smith L, Jenner P, Schoenleber R, and Williams M (1992) A-77636: a potent and selective dopamine D1 receptor agonist with antiparkinsonian activity in marmosets. Eur $J$ Pharmacol 229: 203-209.

Klawans HL and Ringel SP (1973) A clinical study of methysergide in Parkinsonism: evidence against a serotonergic mechanism. J Neurol Sci 19:399-405.

Klawans HL, Jr and Weiner WJ (1974) Attempted use of haloperidol in the treatment of L-dopa induced dyskinesias. J Neurol Neurosurg Psychiatry 37:427-430.

Klockgether T, Turski L, Honoré T, Zhang ZM, Gash DM, Kurlan R, and Greenamyre JT (1991) The AMPA receptor antagonist NBQX has antiparkinsonian effects in monoamine-depleted rats and MPTP-treated monkeys. Ann Neurol 30:717-723.

Ko WK, Li Q, and Bezard E (2014a) Effects of L-tryptophan on L-DOPA-induced dyskinesia in the L-methyl-4-phenyl-1,2,3,6-tetrahydropyridine (MPTP)-treated macaque model of Parkinson's disease. Neurosci Lett 566:72-76.

Ko WK, Pioli E, Li Q, McGuire S, Dufour A, Sherer TB, Bezard E, and Facheris MF (2014b) Combined fenobam and amantadine treatment promotes robust antidyskinetic effects in the 1-methyl-4-phenyl-1,2,3,6-tetrahydropyridine (MPTP) lesioned primate model of Parkinson's disease. Mov Disord 29:772-779.

Ko WKD, Camus SM, Li Q, Yang J, McGuire S, Pioli EY, and Bezard E (2016) An evaluation of istradefylline treatment on Parkinsonian motor and cognitive deficits in 1-methyl-4-phenyl-1,2,3,6-tetrahydropyridine (MPTP)-treated macaque models. Neuropharmacology 110 (Pt A):48-58.

Ko WKD, Li Q, Cheng LY, Morelli M, Carta M, and Bezard E (2017) A preclinical study on the combined effects of repeated eltoprazine and preladenant treatmen for alleviating L-DOPA-induced dyskinesia in Parkinson's disease. Eur J Pharmacol 813:10-16.

Kobylecki C, Burn DJ, Kass-Iliyya L, Kellett MW, Crossman AR, and Silverdale MA (2014) Randomized clinical trial of topiramate for levodopa-induced dyskinesia in Parkinson's disease. Parkinsonism Relat Disord 20:452-455.

Kobylecki C, Cenci MA, Crossman AR, and Ravenscroft P (2010) Calcium-permeable AMPA receptors are involved in the induction and expression of l-DOPA-induced dyskinesia in Parkinson's disease. J Neurochem 114:499-511.

Kobylecki C, Hill MP, Crossman AR, and Ravenscroft P (2011) Synergistic antidyskinetic effects of topiramate and amantadine in animal models of Parkinson's disease. Mov Disord 26:2354-2363.

Koller WC and Herbster G (1987) Adjuvant therapy of parkinsonian tremor. Arch Neurol 44:921-923

Konitsiotis S, Blanchet PJ, Verhagen L, Lamers E, and Chase TN (2000) AMPA receptor blockade improves levodopa-induced dyskinesia in MPTP monkeys. Neurology 54:1589-1595.

Koprich JB, Fox SH, Johnston TH, Goodman A, Le Bourdonnec B, Dolle RE, DeHaven RN, DeHaven-Hudkins DL, Little PJ, and Brotchie JM (2011) The selective mu-opioid receptor antagonist ADL5510 reduces levodopa-induced dyskinesia without affecting antiparkinsonian action in MPTP-lesioned macaque model of Parkinson's disease. Mov Disord 26:1225-1233.

Koprich JB, Huot P, Fox SH, Jarvie K, Lang AE, Seeman P, and Brotchie JM (2013) The effects of fast-off-D2 receptor antagonism on L-DOPA-induced dyskinesia and psychosis in parkinsonian macaques. Prog Neuropsychopharmacol Biol Psychiatry 43:151-156.

Korczyn AD, Brunt ER, Larsen JP, Nagy Z, Poewe WH, and Ruggieri S (1999) A 3 -year randomized trial of ropinirole and bromocriptine in early Parkinson's disease. The 053 Study Group. Neurology 53:364-370.

Kulisevsky J, Pagonabarraga J, Pascual-Sedano B, Gironell A, García-Sánchez C, and Martínez-Corral M (2008) Motor changes during sertraline treatment in depressed patients with Parkinson's disease*. Eur J Neurol 15:953-959.

Lamid S and Jenkins RB (1975) Crossover clinical trial of benapryzine and trihexyphenidyl in Parkinsonian patients. J Clin Pharmacol 15:622-626.

Lange KW, Löschmann PA, Wachtel H, Horowski R, Jähnig P, Jenner P, and Marsden CD (1992) Terguride stimulates locomotor activity at 2 months but not 10 months after 1-methyl-4-phenyl-1,2,3,6-tetrahydropyridine treatment of common marmosets. Eur J Pharmacol 212:247-252.

Langston JW, Ballard P, Tetrud JW, and Irwin I (1983) Chronic Parkinsonism in humans due to a product of meperidine-analog synthesis. Science 219:979-980.

Langston JW, Forno LS, Rebert CS, and Irwin I (1984) Selective nigral toxicity after systemic administration of 1-methyl-4-phenyl-1,2,5,6-tetrahydropyrine (MPTP) in the squirrel monkey. Brain Res 292:390-394.

Lees AJ, Lander CM, and Stern GM (1978) Tiapride and sulpiride in Parkinson's disease. Lancet 2:1205.

Lemay S, Chouinard S, Blanchet P, Masson H, Soland V, Beuter A, and Bédard MA (2004) Lack of efficacy of a nicotine transdermal treatment on motor and cognitive deficits in Parkinson's disease. Prog Neuropsychopharmacol Biol Psychiatry 28: 31-39.

LeWitt PA, Guttman M, Tetrud JW, Tuite PJ, Mori A, Chaikin P, and Sussman NM; 6002-US-005 Study Group (2008) Adenosine A2A receptor antagonist istradefylline (KW-6002) reduces "off" time in Parkinson's disease: a double-blind, randomized, multicenter clinical trial (6002-US-005). Ann Neurol 63:295-302.

Lewitt PA, Hauser RA, Lu M, Nicholas AP, Weiner W, Coppard N, Leinonen M, and Savola JM (2012) Randomized clinical trial of fipamezole for dyskinesia in Parkinson disease (FJORD study). Neurology 79:163-169.

LeWitt PA, Lyons KE, and Pahwa R; SP 650 Study Group (2007) Advanced Parkinson disease treated with rotigotine transdermal system: PREFER study. Neurology 68:1262-1267.
Lieberman A, Ranhosky A, and Korts D (1997) Clinical evaluation of pramipexole in advanced Parkinson's disease: results of a double-blind, placebo-controlled, parallel-group study. Neurology 49:162-168.

Lieberman AN, Gopinathan G, and Neophytides A (1986) Efficacy of pergolide and mesulergine. Eur Neurol 25:86-90.

Lincoln L, Fisher R, Jackson MJ, Jenner P, Neumeyer J, Sromek AW, Lees AJ, and Rose S (2016) Oral r-(-)-11-o-valeryl-n-n-propylnoraporphine reverses motor deficits in mptp-treated marmosets. Mov Disord 31:1381-1388.

Lindeboom SF and Lakke JP (1978) Deanol and physostigmine in the treatment of L-dopa-induced dyskinesias. Acta Neurol Scand 58:134-138.

Löschmann PA, Chong PN, Nomoto M, Tepper PG, Horn AS, Jenner P, and Marsden CD (1989) Stereoselective reversal of MPTP-induced parkinsonism in the marmoset after dermal application of N-0437. Eur J Pharmacol 166:373-380.

Löschmann PA, De Groote C, Smith L, Wüllner U, Fischer G, Kemp JA, Jenner P, and Klockgether T (2004) Antiparkinsonian activity of Ro 25-6981, a NR2B subunit specific NMDA receptor antagonist, in animal models of Parkinson's disease. Exp Neurol 187:86-93.

Löschmann PA, Lange KW, Kunow M, Rettig KJ, Jähnig P, Honoré T, Turski L, Wachtel H, Jenner P, and Marsden CD (1991) Synergism of the AMPA-antagonist NBQX and the NMDA-antagonist CPP with L-dopa in models of Parkinson's disease. J Neural Transm Park Dis Dement Sect 3:203-213.

Löschmann PA, Smith LA, Lange KW, Jähnig P, Jenner P, and Marsden CD (1992) Motor activity following the administration of selective D-1 and D-2 dopaminergic drugs to MPTP-treated common marmosets. Psychopharmacology (Berl) 109: $49-56$.

Luginger E, Wenning GK, Bösch S, and Poewe W (2000) Beneficial effects of amantadine on L-dopa-induced dyskinesias in Parkinson's disease. Mov Disord 15 873-878.

Luquin MR, Laguna J, Herrero MT, and Obeso JA (1993a) Behavioral tolerance to repeated apomorphine administration in parkinsonian monkeys. J Neurol Sci 114: $40-44$

Luquin MR, Laguna J, and Obeso JA (1992) Selective D2 receptor stimulation induces dyskinesia in parkinsonian monkeys. Ann Neurol 31:551-554.

Luquin MR, Obeso JA, Laguna J, Guillén J, and Martínez-Lage JM (1993b) The AMPA receptor antagonist NBQX does not alter the motor response induced by selective dopamine agonists in MPTP-treated monkeys. Eur J Pharmacol 235: 297-300

Mahmoudi S, Samadi P, Gilbert F, Ouattara B, Morissette M, Grégoire L, Rouillard C, Di Paolo T, and Lévesque D (2009) Nur77 mRNA levels and L-Dopa-induced dyskinesias in MPTP monkeys treated with docosahexaenoic acid. Neurobiol Dis 36:213-222.

Manson AJ, Iakovidou E, and Lees AJ (2000) Idazoxan is ineffective for levodopainduced dyskinesias in Parkinson's disease. Mov Disord 15:336-337.

Manson AJ, Katzenschlager R, Hobart J, and Lees AJ (2001) High dose naltrexone for dyskinesias induced by levodopa. J Neurol Neurosurg Psychiatry 70:554-556.

Maratos EC, Jackson MJ, Pearce RK, Cannizzaro C, and Jenner P (2003) Both shortand long-acting D-1/D-2 dopamine agonists induce less dyskinesia than L-DOPA in the MPTP-lesioned common marmoset (Callithrix jacchus). Exp Neurol 179: 90-102.

Maratos EC, Jackson MJ, Pearce RK, and Jenner P (2001) Antiparkinsonian activity and dyskinesia risk of ropinirole and L-DOPA combination therapy in drug naïve MPTP-lesioned common marmosets (Callithrix jacchus). Mov Disord 16:631-641.

Marino S, Sessa E, Di Lorenzo G, Digangi G, Alagna A, Bramanti P, and Di Bella P (2008) Sertraline in the treatment of depressive disorders in patients with Parkinson's disease. Neurol Sci 29:391-395.

Marsden CD, Parkes JD, and Rees JE (1973) A year's comparison of treatment of patients with parkinson's disease with levodopa combined with carbidopa versus treatment with levodopa alone. Lancet 2:1459-1462.

Marti M, Rodi D, Li Q, Guerrini R, Fasano S, Morella I, Tozzi A, Brambilla R, Calabresi P, Simonato M, et al. (2012) Nociceptin/orphanin FQ receptor agonists attenuate L-DOPA-induced dyskinesias. J Neurosci 32:16106-16119.

Martignoni E, Pacchetti C, Aufdembrinke B, Godi L, Albani G, Mancini F, and Nappi G (1995) Terguride in stable Parkinson's disease. Funct Neurol 10:143-146.

Martin WE, Loewenson RB, Resch JA, and Baker AB (1974) A controlled study comparing trihexyphenidyl hydrochloride plus levodopa with placebo plus levodopa in patients with Parkinson's disease. Neurology 24:912-919.

McCall RB, Lookingland KJ, Bédard PJ, and Huff RM (2005) Sumanirole, a highly dopamine D2-selective receptor agonist: in vitro and in vivo pharmacological characterization and efficacy in animal models of Parkinson's disease. J Pharmaco Exp Ther 314:1248-1256.

Meco G, Fabrizio E, Di Rezze S, Alessandri A, and Pratesi L (2003) Mirtazapine in L-dopa-induced dyskinesias. Clin Neuropharmacol 26:179-181.

Meltzer HY, Mills R, Revell S, Williams H, Johnson A, Bahr D, and Friedman JH (2010) Pimavanserin, a serotonin(2A) receptor inverse agonist, for the treatment of parkinson's disease psychosis. Neuropsychopharmacology 35:881-892.

Merello M, Lees AJ, Webster R, Bovingdon M, and Gordin A (1994) Effect of entacapone, a peripherally acting catechol-O-methyltransferase inhibitor, on the motor response to acute treatment with levodopa in patients with Parkinson's disease. $J$ Neurol Neurosurg Psychiatry 57:186-189.

Mestre TA, Shah BB, Connolly BS, de Aquino C, Al Dhakeel A, Walsh R, Ghate T, Lui JP, and Fox SH (2014) Famotidine, a histamine H2 receptor antagonist, does not reduce levodopa-induced dyskinesia in Parkinson's disease: a proof-of-concept study. Mov Disord Clin Pract (Hoboken) 1:219-224.

Millan MJ, Di Cara B, Hill M, Jackson M, Joyce JN, Brotchie J, McGuire S, Crossman A, Smith L, Jenner P, et al. (2004) S32504, a novel naphtoxazine agonist at dopamine D3/D2 receptors. II. Actions in rodent, primate, and cellular models of antiparkinsonian activity in comparison to ropinirole. J Pharmacol Exp Ther $\mathbf{3 0 9}$ 921-935.

Mizuno Y, Kondo T, and Narabayashi H (1995) Pergolide in the treatment of Parkinson's disease. Neurology 45(3 Suppl 3):S13-S21. 
Mizuno Y, Nomoto M, Kondo T, Hasegawa K, Murata M, Takeuchi M, Ikeda J, Tomida T, and Hattori N; Rotigotine Trial Group (2013) Transdermal rotigotine in early stage Parkinson's disease: a randomized, double-blind, placebo-controlled trial. Mov Disord 28:1447-1450.

Molinari SP, Kaminski R, Di Rocco A, and Yahr MD (1995) The use of famotidine in the treatment of Parkinson's disease: a pilot study. J Neural Transm Park Dis Dement Sect 9:243-247.

Montastruc JL, Puech AJ, Clanet M, Guiraud-Chaumeil B, and Rascol A (1981) Yohimbine in treatment of Parkinson's disease: preliminary results (author's transl). Nouv Presse Med 10:1331-1332.

Montastruc JL, Rascol O, Senard JM, and Rascol A (1994) A randomised controlled study comparing bromocriptine to which levodopa was later added, with levodopa alone in previously untreated patients with Parkinson's disease: a five year follow up. J Neurol Neurosurg Psychiatry 57:1034-1038.

Morin N, Grégoire L, Gomez-Mancilla B, Gasparini F, and Di Paolo T (2010) Effect of the metabotropic glutamate receptor type 5 antagonists MPEP and MTEP in parkinsonian monkeys. Neuropharmacology 58:981-986.

Morin N, Grégoire L, Morissette M, Desrayaud S, Gomez-Mancilla B, Gasparini F, and Di Paolo T (2013a) MPEP, an mGlu5 receptor antagonist, reduces the development of L-DOPA-induced motor complications in de novo parkinsonian monkeys: biochemical correlates. Neuropharmacology 66:355-364

Morin N, Morissette M, Grégoire L, and Di Paolo T (2015a) Effect of a chronic treatment with an mGlu5 receptor antagonist on brain serotonin markers in parkinsonian monkeys. Prog Neuropsychopharmacol Biol Psychiatry 56:27-38.

Morin N, Morissette M, Grégoire L, Gomez-Mancilla B, Gasparini F, and Di Paolo T (2013b) Chronic treatment with MPEP, an mGlu5 receptor antagonist, normalizes basal ganglia glutamate neurotransmission in L-DOPA-treated parkinsonian monkeys. Neuropharmacology 73:216-231.

Morin N, Morissette M, Grégoire L, Rajput A, Rajput AH, and Di Paolo T (2015b) Contribution of brain serotonin subtype $1 \mathrm{~B}$ receptors in levodopa-induced motor complications. Neuropharmacology 99:356-368.

Morissette M, Dridi M, Calon F, Hadj Tahar A, Meltzer LT, Bédard PJ, and Di Paolo T (2006a) Prevention of dyskinesia by an NMDA receptor antagonist in MPTP monkeys: effect on adenosine A2A receptors. Synapse 60:239-250.

Morissette M, Dridi M, Calon F, Hadj Tahar A, Meltzer LT, Bédard PJ, and Di Paolo T (2006b) Prevention of levodopa-induced dyskinesias by a selective NR1A/2B $\mathrm{N}$-methyl-D-aspartate receptor antagonist in parkinsonian monkeys: implication of preproenkephalin. Mov Disord 21:9-17.

Morissette M, Goulet M, Grondin R, Blanchet P, Bédard PJ, Di Paolo T, and Lévesque D (1998) Associative and limbic regions of monkey striatum express high levels of dopamine D3 receptors: effects of MPTP and dopamine agonist replacement therapies. Eur J Neurosci 10:2565-2573.

Morissette M, Goulet M, Soghomonian JJ, Blanchet PJ, Calon F, Bédard PJ, and Di Paolo T (1997) Preproenkephalin mRNA expression in the caudate-putamen of MPTP monkeys after chronic treatment with the D2 agonist U91356A in continuous or intermittent mode of administration: comparison with L-DOPA therapy. Brain Res Mol Brain Res 49:55-62.

Morissette M, Grondin R, Goulet M, Bédard PJ, and Di Paolo T (1999) Differential regulation of striatal preproenkephalin and preprotachykinin mRNA levels in MPTP-lesioned monkeys chronically treated with dopamine D1 or D2 receptor agonists. $J$ Neurochem 72:682-692.

Morissette M, Morin N, Grégoire L, Rajput A, Rajput AH, and Di Paolo T (2016) Brain $\alpha 7$ nicotinic acetylcholine receptors in MPTP-lesioned monkeys and parkinsonian patients. Biochem Pharmacol 109:62-69.

Morissette M, Samadi P, Hadj Tahar A, Bélanger N, and Di Paolo T (2010) Striatal Akt/GSK3 signaling pathway in the development of L-Dopa-induced dyskinesias in MPTP monkeys. Prog Neuropsychopharmacol Biol Psychiatry 34:446-454.

Muenter MD, Ahlskog JE, Bell G, and McManis P (1988) PHNO [(+)-4-propyl-9hydroxynaphthoxazine]: a new and effective anti-Parkinson's disease agent. Neurology 38:1541-1545.

Muñoz A, Li Q, Gardoni F, Marcello E, Qin C, Carlsson T, Kirik D, Di Luca M, Björklund A, Bezard E, et al. (2008) Combined 5-HT1A and 5-HT1B receptor agonists for the treatment of L-DOPA-induced dyskinesia. Brain 131:3380-3394.

Nagata T, Shinagawa S, Tagai K, and Nakayama K (2013) A case in which mirtazapine reduced auditory hallucinations in a patient with Parkinson disease. Int Psychogeriatr 25:1199-1201.

Nash JE, Fox SH, Henry B, Hill MP, Peggs D, McGuire S, Maneuf Y, Hille C, Brotchie JM, and Crossman AR (2000) Antiparkinsonian actions of ifenprodil in the MPTP lesioned marmoset model of Parkinson's disease. Exp Neurol 165:136-142.

Nash JE, Ravenscroft P, McGuire S, Crossman AR, Menniti FS, and Brotchie JM (2004) The NR2B-selective NMDA receptor antagonist CP-101,606 exacerbates L-DOPA-induced dyskinesia and provides mild potentiation of anti-parkinsonian effects of L-DOPA in the MPTP-lesioned marmoset model of Parkinson's disease. Exp Neurol 188:471-479.

NINDS Exploratory Trials in Parkinson Disease (NET-PD) FS-ZONE Investigator (2015) Pioglitazone in early Parkinson's disease: a phase 2, multicentre, doubleblind, randomised trial. Lancet Neurol 14:795-803.

Nomoto M, Jenner P, and Marsden CD (1985) The dopamine D2 agonist LY 141865 but not the D1 agonist SKF 38393, reverses parkinsonism induced by 1-methyl-4 phenyl-1,2,3,6-tetrahydropyridine (MPTP) in the common marmoset. Neurosci Lett 57:37-41.

Nomoto M, Jenner P, and Marsden CD (1988) The D1 agonist SKF 38393 inhibits the antiparkinsonian activity of the D2 agonist LY 171555 in the MPTP-treated marmoset. Neurosci Lett 93:275-280.

Nomoto M, Stahl S, Jenner P, and Marsden CD (1987) Antiparkinsonian activity of (+)-PHNO in the MPTP-treated common marmoset. Mov Disord 2:37-45.

Nutt JG, Gunzler SA, Kirchhoff T, Hogarth P, Weaver JL, Krams M, Jamerson B, Menniti FS, and Landen JW (2008) Effects of a NR2B selective NMDA glutamate antagonist, CP-101,606, on dyskinesia and Parkinsonism. Mov Disord 23: $1860-1866$
Oertel W, Eggert K, Pahwa R, Tanner CM, Hauser RA, Trenkwalder C, Ehret R, Azulay JP, Isaacson S, Felt L, et al. (2017) Randomized, placebo-controlled trial of ADS-5102 (amantadine) extended-release capsules for levodopa-induced dyskinesia in Parkinson's disease (EASE LID 3). Mov Disord 31:1701-1709.

Oertel WH, Wolters E, Sampaio C, Gimenez-Roldan S, Bergamasco B, Dujardin M, Grosset DG, Arnold G, Leenders KL, Hundemer HP, et al. (2006) Pergolide versus levodopa monotherapy in early Parkinson's disease patients: the PELMOPET study. Mov Disord 21:343-353.

Oh JD, Bibbiani F, and Chase TN (2002) Quetiapine attenuates levodopa-induced motor complications in rodent and primate parkinsonian models. Exp Neurol 177: $557-564$

Olanow CW, Damier P, Goetz CG, Mueller T, Nutt J, Rascol O, Serbanescu A Deckers F, and Russ H (2004) Multicenter, open-label, trial of sarizotan in Parkinson disease patients with levodopa-induced dyskinesias (the SPLENDID study). Clin Neuropharmacol 27:58-62.

Olanow CW, Fahn S, Muenter M, Klawans H, Hurtig H, Stern M, Shoulson I, Kurlan R, Grimes JD, Jankovic J, et al. (1994) A multicenter double-blind placebocontrolled trial of pergolide as an adjunct to Sinemet in Parkinson's disease. Mov Disord 9:40-47.

Ondo WG, Tintner R, Voung KD, Lai D, and Ringholz G (2005) Double-blind, placebocontrolled, unforced titration parallel trial of quetiapine for dopaminergic-induced hallucinations in Parkinson's disease. Mov Disord 20:958-963.

Ouattara B, Belkhir S, Morissette M, Dridi M, Samadi P, Grégoire L, Meltzer LT, and Di Paolo T (2009) Implication of NMDA receptors in the antidyskinetic activity of cabergoline, CI-1041, and Ro 61-8048 in MPTP monkeys with levodopa-induced dyskinesias. J Mol Neurosci 38:128-142.

Ouattara B, Grégoire L, Morissette M, Gasparini F, Vranesic I, Bilbe G, Johns DR Rajput A, Hornykiewicz O, Rajput AH, et al. (2011) Metabotropic glutamate receptor type 5 in levodopa-induced motor complications. Neurobiol Aging 32. $1286-1295$

Ouattara B, Hoyer D, Grégoire L, Morissette M, Gasparini F, Gomez-Mancilla B, and Di Paolo T (2010) Changes of AMPA receptors in MPTP monkeys with levodopa-induced dyskinesias. Neuroscience 167:1160-1167.

Pahwa R, Tanner CM, Hauser RA, Isaacson SH, Nausieda PA, Truong DD, Agarwal P, Hull KL, Lyons KE, Johnson R, et al. (2017) ADS-5102 (Amantadine) extendedrelease capsules for levodopa-induced dyskinesia in Parkinson disease (EASE LID study): a randomized clinical trial. JAMA Neurol 74:941-949.

Pålhagen SE, Carlsson M, Curman E, Wålinder J, and Granérus AK (2008) Depressive illness in Parkinson's disease-indication of a more advanced and widespread neurodegenerative process? Acta Neurol Scand 117:295-304.

Pålhagen SE, Ekberg S, Wålinder J, Granérus AK, and Granerus G (2009) HMPAO SPECT in Parkinson's disease (PD) with major depression (MD) before and after antidepressant treatment. $J$ Neurol 256:1510-1518.

Papa SM, Auberson YP, and Greenamyre JT (2004) Prolongation of levodopa responses by glycineB antagonists in parkinsonian primates. Ann Neurol 56: $723-727$.

Papa SM and Chase TN (1996) Levodopa-induced dyskinesias improved by a glutamate antagonist in Parkinsonian monkeys. Ann Neurol 39:574-578.

Park DM, Findley LJ, Hanks G, and Sandler M (1981) Nomifensine: effect in Parkinsonian patients not receiving levodopa. J Neurol Neurosurg Psychiatry 44: $352-354$.

Park DM, Findley LJ, and Teychenne PF (1977) Nomifensine in parkinsonism. $B r J$ Clin Pharmacol (4 Suppl 2)185S-186S.

Parkes JD, Baxter RC, Curzon G, Knill-Jones RP, Knott PJ, Marsden CD, Tattersall R, and Vollum D (1971) Treatment of Parkinson's disease with amantadine and levodopa: a one-year study. Lancet 1:1083-1086.

Parkinson Study Group (1999) Low-dose clozapine for the treatment of drug-induced psychosis in Parkinson's disease. N Engl J Med 340:757-763.

Parkinson Study Group (2000a) A multicenter randomized controlled trial of remacemide hydrochloride as monotherapy for PD. Neurology 54:1583-1588.

Parkinson Study Group (2000b) Pramipexole vs levodopa as initial treatment for Parkinson disease: a randomized controlled trial. JAMA 284:1931-1938.

Parkinson Study Group (2001) Evaluation of dyskinesias in a pilot, randomized placebo-controlled trial of remacemide in advanced Parkinson disease. Arch Neurol 58:1660-1668

Parkinson Study Group (2003) A controlled trial of rotigotine monotherapy in early Parkinson's disease. Arch Neurol 60:1721-1728.

Parkinson Study Group (2005) A randomized placebo-controlled trial of rasagiline in levodopa-treated patients with Parkinson disease and motor fluctuations: the PRESTO study. Arch Neurol 62:241-248.

Pearce RK, Banerji T, Jenner P, and Marsden CD (1998) De novo administration of ropinirole and bromocriptine induces less dyskinesia than L-dopa in the MPTPtreated marmoset. Mov Disord 13:234-241.

Pearce RK, Jackson M, Britton DR, Shiosaki K, Jenner P, and Marsden CD (1999) Actions of the D1 agonists A-77636 and A-86929 on locomotion and dyskinesia in MPTP-treated L-dopa-primed common marmosets. Psychopharmacology (Berl) 142:51-60

Pearce RK, Jackson M, Smith L, Jenner P, and Marsden CD (1995) Chronic L-DOPA administration induces dyskinesias in the 1-methyl-4- phenyl-1,2,3,6-tetrahydropyridinetreated common marmoset (Callithrix jacchus). Mov Disord 10:731-740.

Pearce RK, Smith LA, Jackson MJ, Banerji T, Scheel-Krüger J, and Jenner P (2002) The monoamine reuptake blocker brasofensine reverses akinesia without dyskinesia in MPTP-treated and levodopa-primed common marmosets. Mov Disord 17: 877-886.

Pessiglione M, Guehl D, Hirsch EC, Féger J, and Tremblay L (2004a) Disruption of self-organized actions in monkeys with progressive MPTP-induced parkinsonism. I. Effects of task complexity. Eur $J$ Neurosci 19:426-436.

Pessiglione M, Guehl D, Jan C, François C, Hirsch EC, Féger J, and Tremblay L (2004b) Disruption of self-organized actions in monkeys with progressive MPTPinduced parkinsonism: II. Effects of reward preference. Eur J Neurosci 19:437-446. 
Philippens IH, Joosen MJ, Ahnaou A, Andres I, and Drinkenburg WP (2014) AntiParkinson effects of a selective alpha2C-adrenoceptor antagonist in the MPTP marmoset model. Behav Brain Res 269:81-86.

Pinna A, Ko WK, Costa G, Tronci E, Fidalgo C, Simola N, Li Q, Tabrizi MA, Bezard E, Carta M, et al. (2016) Antidyskinetic effect of A2A and 5HT1A/1B receptor ligands in two animal models of Parkinson's disease. Mov Disord 31:501-511.

Poewe WH, Rascol O, Quinn N, Tolosa E, Oertel WH, Martignoni E, Rupp M, and Boroojerdi B; SP 515 Investigators (2007) Efficacy of pramipexole and transdermal rotigotine in advanced Parkinson's disease: a double-blind, double-dummy, randomised controlled trial. Lancet Neurol 6:513-520.

Porras G, Li Q, and Bezard E (2012) Modeling Parkinson's disease in primates: the MPTP model. Cold Spring Harb Perspect Med 2:a009308.

Potts LF, Park ES, Woo JM, Dyavar Shetty BL, Singh A, Braithwaite SP, Voronkov M, Papa SM, and Mouradian MM (2015) Dual $\kappa$-agonist/ $\mu$-antagonist opioid receptor modulation reduces levodopa-induced dyskinesia and corrects dysregulated striatal changes in the nonhuman primate model of Parkinson disease. Ann Neurol 77:930-941.

Pourcher E, Bonnet AM, Kefalos J, Dubois B, and Agid Y (1989) Effects of etybenzatropine and diazepam on levodopa-induced diphasic dyskinesias in Parkinson's disease. Mov Disord 4:195-201.

Pourcher E, Fernandez HH, Stacy M, Mori A, Ballerini R, and Chaikin P (2012) Istradefylline for Parkinson's disease patients experiencing motor fluctuations: results of the KW-6002-US-018 study. Parkinsonism Relat Disord 18:178-184.

Pourcher E, Gomez-Mancilla B, and Bédard PJ (1992) Ethosuximide and tremor in Parkinson's disease: a pilot study. Mov Disord 7:132-136.

Quik M, Cox H, Parameswaran N, O'Leary K, Langston JW, and Di Monte D (2007) Nicotine reduces levodopa-induced dyskinesias in lesioned monkeys. Ann Neurol 62:588-596.

Quik M, Mallela A, Chin M, McIntosh JM, Perez XA, and Bordia T (2013a) Nicotinemediated improvement in L-dopa-induced dyskinesias in MPTP-lesioned monkeys is dependent on dopamine nerve terminal function. Neurobiol Dis 50:30-41.

Quik M, Mallela A, Ly J, and Zhang D (2013b) Nicotine reduces established levodopainduced dyskinesias in a monkey model of Parkinson's disease. Mov Disord 28 1398-1406.

Quinn N, Illas A, Lhermitte F, and Agid Y (1981) Bromocriptine and domperidone in the treatment of Parkinson disease. Neurology 31:662-667.

Rampello L, Chiechio S, Raffaele R, Vecchio I, and Nicoletti F (2002) The SSRI, citalopram, improves bradykinesia in patients with Parkinson's disease treated with L-dopa. Clin Neuropharmacol 25:21-24.

Rascol O, Arnulf I, Peyro-Saint Paul H, Brefel-Courbon C, Vidailhet M, Thalamas C, Bonnet AM, Descombes S, Bejjani B, Fabre N, et al. (2001a) Idazoxan, an alpha-2 antagonist, and L-DOPA-induced dyskinesias in patients with Parkinson's disease. Mov Disord 16:708-713.

Rascol O, Blin O, Thalamas C, Descombes S, Soubrouillard C, Azulay P, Fabre N, Viallet F, Lafnitzegger K, Wright S, et al. (1999) ABT-431, a D1 receptor agonist prodrug, has efficacy in Parkinson's disease. Ann Neurol 45:736-741.

Rascol O, Bronzova J, Hauser RA, Lang AE, Sampaio C, Theeuwes A, and van de Witte SV (2012) Pardoprunox as adjunct therapy to levodopa in patients with Parkinson's disease experiencing motor fluctuations: results of a double-blind, randomized, placebo-controlled, trial. Parkinsonism Relat Disord 18:370-376.

Rascol O, Brooks DJ, Korczyn AD, De Deyn PP, Clarke CE, and Lang AE (2000) A five-year study of the incidence of dyskinesia in patients with early Parkinson's disease who were treated with ropinirole or levodopa. $N$ Engl J Med 342 1484-1491.

Rascol O, Brooks DJ, Korczyn AD, De Deyn PP, Clarke CE, Lang AE, and Abdalla M; 056 Study Group (2006a) Development of dyskinesias in a 5-year trial of ropinirole and L-dopa. Mov Disord 21:1844-1850.

Rascol O, Brooks DJ, Melamed E, Oertel W, Poewe W, Stocchi F, and Tolosa E; LARGO study group (2005) Rasagiline as an adjunct to levodopa in patients with Parkinson's disease and motor fluctuations (LARGO, lasting effect in adjunct therapy with rasagiline given once daily, study): a randomised, double-blind, parallel-group trial. Lancet 365:947-954.

Rascol O, Dubois B, Caldas AC, Senn S, Del Signore S, and Lees A; Parkinson REGAIN Study Group (2006b) Early piribedil monotherapy of Parkinson's disease: a planned seven-month report of the REGAIN study. Mov Disord 21:2110-2115.

Rascol O, Fabre N, Blin O, Poulik J, Sabatini U, Senard JM, Ané M, Montastruc JL, and Rascol A (1994) Naltrexone, an opiate antagonist, fails to modify motor symptoms in patients with Parkinson's disease. Mov Disord 9:437-440

Rascol O, Lees AJ, Senard JM, Pirtosek Z, Montastruc JL, and Fuell D (1996) Ropinirole in the treatment of levodopa-induced motor fluctuations in patients with Parkinson's disease. Clin Neuropharmacol 19:234-245.

Rascol O, Nutt JG, Blin O, Goetz CG, Trugman JM, Soubrouillard C, Carter JH, Currie LJ, Fabre N, Thalamas C, et al. (2001b) Induction by dopamine D1 receptor agonist ABT-431 of dyskinesia similar to levodopa in patients with Parkinson disease. Arch Neurol 58.249-254.

Riahi G, Morissette M, Lévesque D, Rouillard C, Samadi P, Parent M, and Di Paolo T (2012) Effect of chronic l-DOPA treatment on 5-HT(1A) receptors in parkinsonian monkey brain. Neurochem Int 61:1160-1171.

Riahi G, Morissette M, Parent M, and Di Paolo T (2011) Brain 5-HT(2A) receptors in MPTP monkeys and levodopa-induced dyskinesias. Eur J Neurosci 33:1823-1831.

Riahi G, Morissette M, Samadi P, Parent M, and Di Paolo T (2013) Basal ganglia serotonin $1 \mathrm{~B}$ receptors in parkinsonian monkeys with L-DOPA-induced dyskinesia Biochem Pharmacol 86:970-978.

Rinne UK, Birket-Smith E, Dupont E, Hansen E, Hyyppä M, Marttila R, Mikkelsen B, Pakkenberg H, and Presthus J (1975) Levodopa alone and in combination with a peripheral decarboxylase inhibitor benserazide (Madopar) in the treatment of Parkinson's disease: a controlled clinical trial. J Neurol 211:1-9.

Rinne UK, Bracco F, Chouza C, Dupont E, Gershanik O, Marti Masso JF, Montastruc JL, Marsden CD, Dubini A, Orlando N, et al. (1997) Cabergoline in the treatment of early Parkinson's disease: results of the first year of treatment in a double-blind comparison of cabergoline and levodopa. The PKDS009 collaborative study group. Neurology 48:363-368.

Rose S, Jackson MJ, Smith LA, Stockwell K, Johnson L, Carminati P, and Jenner P (2006) The novel adenosine A2a receptor antagonist ST1535 potentiates the effects of a threshold dose of L-DOPA in MPTP treated common marmosets. Eur $J$ Pharmacol 546:82-87.

Rose S, Scheller DK, Breidenbach A, Smith L, Jackson M, Stockwell K, and Jenner P (2007) Plasma levels of rotigotine and the reversal of motor deficits in MPTP treated primates. Behav Pharmacol 18:155-160.

Rouillard C, Bédard PJ, and Di Paolo T (1990) Effects of chronic treatment of MPTP monkeys with bromocriptine alone or in combination with SKF 38393. Eur $J$ Pharmacol 185:209-215.

Rylander D, Iderberg H, Li Q, Dekundy A, Zhang J, Li H, Baishen R, Danysz W, Bezard E, and Cenci MA (2010) A mGluR5 antagonist under clinical development improves L-DOPA-induced dyskinesia in parkinsonian rats and monkeys. Neurobiol Dis 39:352-361.

Samadi P, Grégoire L, and Bédard PJ (2003) Opioid antagonists increase the dyskinetic response to dopaminergic agents in parkinsonian monkeys: interaction between dopamine and opioid systems. Neuropharmacology 45:954-963.

Samadi P, Grégoire L, and Bédard PJ (2004) The opioid agonist morphine decreases the dyskinetic response to dopaminergic agents in parkinsonian monkeys. Neurobiol Dis 16:246-253.

Samadi P, Grégoire L, Hadj Tahar A, Di Paolo T, Rouillard C, and Bédard PJ (2005a) Naltrexone in the short-term decreases antiparkinsonian response to l-Dopa and in the long-term increases dyskinesias in drug-naïve parkinsonian monkeys. Neuropharmacology 49:165-173.

Samadi P, Grégoire L, Morissette M, Calon F, Hadj Tahar A, Bélanger N, Dridi M, Bédard PJ, and Di Paolo T (2008a) Basal ganglia group II metabotropic glutamate receptors specific binding in non-human primate model of L-Dopa-induced dyskinesias. Neuropharmacology 54:258-268.

Samadi P, Grégoire L, Morissette M, Calon F, Hadj Tahar A, Dridi M, Belanger N, Meltzer LT, Bédard PJ, and Di Paolo T (2008b) mGluR5 metabotropic glutamate receptors and dyskinesias in MPTP monkeys. Neurobiol Aging 29: 1040-1051.

Samadi P, Grégoire L, Rassoulpour A, Guidetti P, Izzo E, Schwarcz R, and Bédard PJ (2005b) Effect of kynurenine 3-hydroxylase inhibition on the dyskinetic and antiparkinsonian responses to levodopa in Parkinsonian monkeys. Mov Disord 20 $792-802$

Samadi P, Grégoire L, Rouillard C, and Bédard PJ (2005c) Dyskinesias occur in response to saline and naltrexone alone after priming with combination of dopaminergic agents and naltrexone in the MPTP parkinsonian monkeys. Neurobiol Dis 19:266-272.

Samadi P, Grégoire L, Rouillard C, Bédard PJ, Di Paolo T, and Lévesque D (2006) Docosahexaenoic acid reduces levodopa-induced dyskinesias in 1-methyl-4-phenyl1,2,3,6-tetrahydropyridine monkeys. Ann Neurol 59:282-288.

Samadi P, Morissette M, Calon F, Hadj Tahar A, Dridi M, Belanger N, Meltzer LT, Bédard PJ, and Di Paolo T (2008c) Normalization of GABAA receptor specific binding in the substantia nigra reticulata and the prevention of L-dopa-induced dyskinesias in MPTP parkinsonian monkeys. Synapse 62:101-109.

Samadi P, Morissette M, Lévesque D, and Di Paolo T (2010) BDNF levels are not related with levodopa-induced dyskinesias in MPTP monkeys. Mov Disord 25 116-121.

Sampaio C, Bronzova J, Hauser RA, Lang AE, Rascol O, van de Witte SV and Theeuwes AA; Rembrandt/Vermeer Study Groups (2011) Pardoprunox in early Parkinson's disease: results from 2 large, randomized double-blind trials. Mov Disord 26:1464-1476.

Savola JM, Hill M, Engstrom M, Merivuori H, Wurster S, McGuire SG, Fox SH, Crossman AR, and Brotchie JM (2003) Fipamezole (JP-1730) is a potent alpha2 adrenergic receptor antagonist that reduces levodopa-induced dyskinesia in the MPTP-lesioned primate model of Parkinson's disease. Mov Disord 18:872-883.

Schapira AH, Fox SH, Hauser RA, Jankovic J, Jost WH, Kenney C, Kulisevsky J Pahwa R, Poewe W, and Anand R (2017) Assessment of safety and efficacy of safinamide as a levodopa adjunct in patients with Parkinson disease and motor fluctuations: a randomized clinical trial. JAMA Neurol 74:216-224.

Schwab RS, Amador LV, and Lettvin JY (1951) Apomorphine in Parkinson's disease. Trans Am Neurol Assoc 56:251-253.

Serrano-Dueñas M (2000) Acute pharmacological test with clonidine for the tremor in patients with Parkinson disease. Rev Neurol 30:910-913.

Shen W, Plotkin JL, Francardo V, Ko WK, Xie Z, Li Q, Fieblinger T, Wess J, Neubig $\mathrm{RR}$, Lindsley CW, et al. (2015) M4 muscarinic receptor signaling ameliorates striatal plasticity deficits in models of L-DOPA-induced dyskinesia. Neuron 88 : $762-773$.

Shiosaki K, Jenner P, Asin KE, Britton DR, Lin CW, Michaelides M, Smith L, Bianchi B, Didomenico S, Hodges L, et al. (1996) ABT-431: the diacetyl prodrug of A-86929, a potent and selective dopamine D1 receptor agonist: in vitro characterization and effects in animal models of Parkinson's disease. J Pharmacol Exp Ther 276:150-160.

Shoulson I and Chase TN (1976) Clonidine and the anti-parkinsonian response to L-DOPA or piribedil. Neuropharmacology 15:25-27.

Shoulson I, Penney J, McDermott M, Schwid S, Kayson E, Chase T, Fahn S, Greenamyre JT, Lang A, Siderowf A, et al.; Parkinson Study Group (2001) A randomized, controlled trial of remacemide for motor fluctuations in Parkinson's disease. Neurology 56:455-462.

Sieradzan KA, Fox SH, Hill M, Dick JP, Crossman AR, and Brotchie JM (2001) Cannabinoids reduce levodopa-induced dyskinesia in Parkinson's disease: a pilot study. Neurology 57:2108-2111.

Silverdale MA, Crossman AR, and Brotchie JM (2002) Striatal AMPA receptor binding is unaltered in the MPTP-lesioned macaque model of Parkinson's disease and dyskinesia. Exp Neurol 174:21-28. 
Silverdale MA, Nicholson SL, Crossman AR, and Brotchie JM (2005) Topiramate reduces levodopa-induced dyskinesia in the MPTP-lesioned marmoset model of Parkinson's disease. Mov Disord 20:403-409.

Silverdale MA, Nicholson SL, Ravenscroft P, Crossman AR, Millan MJ, and Brotchie JM (2004) Selective blockade of $\mathrm{D}(3)$ dopamine receptors enhances the antiparkinsonian properties of ropinirole and levodopa in the MPTP-lesioned primate. Exp Neurol 188:128-138.

Singer C, Lamb J, Ellis A, and Layton G; Sumanirole for Early Parkinson's Disease Study Group (2007) A comparison of sumanirole versus placebo or ropinirole for the treatment of patients with early Parkinson's disease. Mov Disord 22:476-482.

Smith CP, Oh JD, Bibbiani F, Collins MA, Avila I, and Chase TN (2007) Tamoxifen effect on L-DOPA induced response complications in parkinsonian rats and primates. Neuropharmacology 52:515-526.

Smith L, De Salvia M, Jenner P, and Marsden CD (1996) An appraisal of the antiparkinsonian activity of piribedil in 1-methyl-4-phenyl-1,2,3,6-tetrahydropyridinetreated common marmosets. Mov Disord 11:125-135.

Smith LA, Gordin A, Jenner P, and Marsden CD (1997) Entacapone enhances levodopa-induced reversal of motor disability in MPTP-treated common marmosets. Mov Disord 12:935-945.

Smith LA, Jackson MG, Bonhomme C, Chezaubernard C, Pearce RK, and Jenner P (2000) Transdermal administration of piribedil reverses MPTP-induced motor deficits in the common marmoset. Clin Neuropharmacol 23:133-142.

Smith LA, Jackson MJ, Al-Barghouthy G, and Jenner P (2002a) The actions of a D-1 agonist in MPTP treated primates show dependence on both D-1 and D-2 receptor function and tolerance on repeated administration. J Neural Transm (Vienna) 109 123-140.

Smith LA, Jackson MJ, Al-Barghouthy G, Rose S, Kuoppamaki M, Olanow W, and Jenner P (2005) Multiple small doses of levodopa plus entacapone produce continuous dopaminergic stimulation and reduce dyskinesia induction in MPTPtreated drug-naive primates. Mov Disord 20:306-314.

Smith LA, Jackson MJ, Hansard MJ, Maratos E, and Jenner P (2003) Effect of pulsatile administration of levodopa on dyskinesia induction in drug-naïve MPTPtreated common marmosets: effect of dose, frequency of administration, and brain exposure. Mov Disord 18:487-495.

Smith LA, Jackson MJ, Johnston L, Kuoppamaki M, Rose S, Al-Barghouthy G, Del Signore S, and Jenner P (2006) Switching from levodopa to the long-acting dopamine D2/D3 agonist piribedil reduces the expression of dyskinesia while maintaining effective motor activity in MPTP-treated primates. Clin Neuropharmaco 29:112-125.

Smith LA, Tel BC, Jackson MJ, Hansard MJ, Braceras R, Bonhomme C, Chezaubernard C, Del Signore S, Rose S, and Jenner P (2002b) Repeated administration of piribedil induces less dyskinesia than L-dopa in MPTP-treated common marmosets: a behavioural and biochemical investigation. Mov Disord 17:887-901.

Soghomonian JJ, Pedneault S, Audet G, and Parent A (1994) Increased glutamate decarboxylase mRNA levels in the striatum and pallidum of MPTP-treated primates. J Neurosci 14:6256-6265.

Stathis P, Konitsiotis S, Tagaris G, and Peterson D; VALID-PD Study Group (2011) Levetiracetam for the management of levodopa-induced dyskinesias in Parkinson's disease. Mov Disord 26:264-270.

Steece-Collier K, Chambers LK, Jaw-Tsai SS, Menniti FS, and Greenamyre JT (2000) Antiparkinsonian actions of CP-101,606, an antagonist of NR2B subunitcontaining N-methyl-d-aspartate receptors. Exp Neurol 163:239-243.

Stibe C, Lees A, and Stern G (1987) Subcutaneous infusion of apomorphine and lisuride in the treatment of parkinsonian on-off fluctuations. Lancet 1:871.

Stocchi F, Rascol O, Destee A, Hattori N, Hauser RA, Lang AE, Poewe W, Stacy M, Tolosa E, Gao H, et al. (2013) AFQ056 in Parkinson patients with levodopa-induced dyskinesia: 13-week, randomized, dose-finding study. Mov Disord 28:1838-1846.

Stocchi F, Rascol O, Hauser RA, Huyck S, Tzontcheva A, Capece R, Ho TW, Sklar P, Lines C, Michelson D, et al.; Preladenant Early Parkinson Disease Study Group (2017) Randomized trial of preladenant, given as monotherapy, in patients with early Parkinson disease. Neurology 88:2198-2206.

Stockwell KA, Scheller D, Rose S, Jackson MJ, Tayarani-Binazir K, Iravani MM, Smith LA, Olanow CW, and Jenner P (2009) Continuous administration of rotigotine to MPTP-treated common marmosets enhances anti-parkinsonian activity and reduces dyskinesia induction. Exp Neurol 219:533-542.

Stockwell KA, Scheller DK, Smith LA, Rose S, Iravani MM, Jackson MJ, and Jenner $\mathrm{P}$ (2010) Continuous rotigotine administration reduces dyskinesia resulting from pulsatile treatment with rotigotine or L-DOPA in MPTP-treated common marmosets. Exp Neurol 221:79-85.

Stockwell KA, Virley DJ, Perren M, Iravani MM, Jackson MJ, Rose S, and Jenner P (2008) Continuous delivery of ropinirole reverses motor deficits without dyskinesia induction in MPTP-treated common marmosets. Exp Neurol 211:172-179.

Stoessl AJ, Mak E, and Calne DB (1985) (+)-4-Propyl-9-hydroxynaphthoxazine (PHNO), a new dopaminomimetic, in treatment of parkinsonism. Lancet $\mathbf{2}$ $1330-1331$.

Svenningsson P, Rosenblad C, Af Edholm Arvidsson K, Wictorin K, Keywood C, Shankar B, Lowe DA, Björklund A, and Widner H (2015) Eltoprazine counteract l-DOPA-induced dyskinesias in Parkinson's disease: a dose-finding study. Brain 138:963-973.

Tagai K, Nagata T, Shinagawa S, Tsuno N, Ozone M, and Nakayama K (2013) Mirtazapine improves visual hallucinations in Parkinson's disease: a case report. Psychogeriatrics 13:103-107.

Tamim MK, Samadi P, Morissette M, Grégoire L, Ouattara B, Lévesque D, Rouillard C, and Di Paolo T (2010) Effect of non-dopaminergic drug treatment on Levodopa induced dyskinesias in MPTP monkeys: common implication of striatal neuropeptides. Neuropharmacology 58:286-296.

Tarsy D, Leopold N, and Sax DS (1974) Physostigmine in choreiform movement disorders. Neurology 24:28-33.

Tayarani-Binazir K, Jackson MJ, Rose S, McCreary AC, and Jenner P (2010a) The partial dopamine agonist pardoprunox (SLV308) administered in combination with 1-dopa improves efficacy and decreases dyskinesia in MPTP treated common marmosets. Exp Neurol 226:320-327.

Tayarani-Binazir KA, Jackson MJ, Rose S, Olanow CW, and Jenner P (2010b) Pramipexole combined with levodopa improves motor function but reduces dyskinesia in MPTP-treated common marmosets. Mov Disord 25:377-384.

Temlett JA, Chong PN, Oertel WH, Jenner P, and Marsden CD (1988) The D-1 dopamine receptor partial agonist, CY 208-243, exhibits antiparkinsonian activity in the MPTP-treated marmoset. Eur J Pharmacol 156:197-206.

Temlett JA, Quinn NP, Jenner PG, Marsden CD, Pourcher E, Bonnet AM, Agid Y, Markstein R, and Lataste X (1989) Antiparkinsonian activity of CY 208-243, a partial D-1 dopamine receptor agonist, in MPTP-treated marmosets and patients with Parkinson's disease. Mov Disord 4:261-265.

Teychenne PF, Park DM, Findley LJ, Rose FC, and Calne DB (1976) Nomifensine in parkinsonism. J Neurol Neurosurg Psychiatry 39:1219-1221.

Tison F, Keywood C, Wakefield M, Durif F, Corvol JC, Eggert K, Lew M, Isaacson S, Bezard E, Poli SM, et al. (2016) A phase 2A trial of the novel mGluR5-negative allosteric modulator dipraglurant for levodopa-induced dyskinesia in Parkinson's disease. Mov Disord 31:1373-1380.

Tison F, Nègre-Pagès L, Meissner WG, Dupouy S, Li Q, Thiolat ML, Thiollier T, Galitzky M, Ory-Magne F, Milhet A, et al. (2013) Simvastatin decreases levodopainduced dyskinesia in monkeys, but not in a randomized, placebo-controlled, multiple cross-over ("n-of-1") exploratory trial of simvastatin against levodopainduced dyskinesia in Parkinson's disease patients. Parkinsonism Relat Disord 19: 416-421.

Trabucchi M, Bassi S, and Frattola L (1982) Effect of naloxone on the "on-off' syndrome in patients receiving long-term levodopa therapy. Arch Neurol 39:120-121.

Trenkwalder C, Berg D, Rascol O, Eggert K, Ceballos-Baumann A, Corvol JC, Storch A, Zhang L, Azulay JP, Broussolle E, et al. (2016a) A placebo-controlled trial of AQW051 in patients with moderate to severe levodopa-induced dyskinesia. Mov Disord 31:1049-1054.

Trenkwalder C, Stocchi F, Poewe W, Dronamraju N, Kenney C, Shah A, von Raison F, and Graf A (2016b) Mavoglurant in Parkinson's patients with l-Dopa-induced dyskinesias: two randomized phase 2 studies. Mov Disord 31:1054-1058.

Treseder SA, Jackson M, and Jenner P (2000) The effects of central aromatic amino acid DOPA decarboxylase inhibition on the motor actions of L-DOPA and dopamine agonists in MPTP-treated primates. Br J Pharmacol 129:1355-1364.

Tsui JK, Wolters EC, Peppard RF, and Calne DB (1989) A double-blind, placebocontrolled, dose-ranging study to investigate the safety and efficacy of CY 208-243 in patients with Parkinson's disease. Neurology 39:856-858.

Tyne H, Brooks J, Taylor J, Vinjamuri S, Baker G, and Steiger M (2007) A double blind placebo controlled study of modafinil for Parkinson's disease related fatigue. Parkinsonism Relat Disord 13 (Suppl 2):S113-S114.

Tyne HL, Taylor J, Baker GA, and Steiger MJ (2010) Modafinil for Parkinson's disease fatigue. J Neurol 257:452-456.

Uchida S, Soshiroda K, Okita E, Kawai-Uchida M, Mori A, Jenner P, and Kanda T (2015a) The adenosine A2A receptor antagonist, istradefylline enhances antiparkinsonian activity induced by combined treatment with low doses of L-DOPA and dopamine agonists in MPTP-treated common marmosets. Eur J Pharmacol 766: $25-30$

Uchida S, Soshiroda K, Okita E, Kawai-Uchida M, Mori A, Jenner P, and Kanda T (2015b) The adenosine A2A receptor antagonist, istradefylline enhances the antiparkinsonian activity of low doses of dopamine agonists in MPTP-treated common marmosets. Eur J Pharmacol 747:160-165.

Uchida S, Tashiro T, Kawai-Uchida M, Mori A, Jenner P, and Kanda T (2014) Adenosine $\mathrm{A}_{2} \mathrm{~A}$-receptor antagonist istradefylline enhances the motor response of L-DOPA without worsening dyskinesia in MPTP-treated common marmosets. $J$ Pharmacol Sci 124:480-485.

van der Stelt M, Fox SH, Hill M, Crossman AR, Petrosino S, Di Marzo V, and Brotchie JM (2005) A role for endocannabinoids in the generation of parkinsonism and levodopa-induced dyskinesia in MPTP-lesioned non-human primate models of Parkinson's disease. FASEB J 19:1140-1142.

van Vliet SA, Vanwersch RA, Jongsma MJ, Olivier B, and Philippens IH (2008) Therapeutic effects of Delta9-THC and modafinil in a marmoset Parkinson model. Eur Neuropsychopharmacol 18:383-389.

Vanover KE, Betz AJ, Weber SM, Bibbiani F, Kielaite A, Weiner DM, Davis RE, Chase TN, and Salamone JD (2008) A 5-HT2A receptor inverse agonist, ACP-103, reduces tremor in a rat model and levodopa-induced dyskinesias in a monkey model. Pharmacol Biochem Behav 90:540-544.

Verhagen Metman L, Del Dotto P, van den Munckhof P, Fang J, Mouradian MM, and Chase TN (1998) Amantadine as treatment for dyskinesias and motor fluctuations in Parkinson's disease. Neurology 50:1323-1326.

Vermeulen RJ, Drukarch B, Sahadat MC, Goosen C, Schoffelmeer AN, Wolters EC, and Stoof JC (1995) Morphine and naltrexone modulate D2 but not D1 receptor induced motor behavior in MPTP-lesioned monkeys. Psychopharmacology (Berl) 118:451-459.

Vieregge A, Sieberer M, Jacobs H, Hagenah JM, and Vieregge P (2001) Transdermal nicotine in PD: a randomized, double-blind, placebo-controlled study. Neurology $\mathbf{5 7}$ 1032-1035.

Villafane G, Cesaro P, Rialland A, Baloul S, Azimi S, Bourdet C, Le Houezec J, Macquin-Mavier I, and Maison P (2007) Chronic high dose transdermal nicotine in Parkinson's disease: an open trial. Eur J Neurol 14:1313-1316.

Visanji NP, de Bie RM, Johnston TH, McCreary AC, Brotchie JM, and Fox SH (2008) The nociceptin/orphanin FQ (NOP) receptor antagonist J-113397 enhances the effects of levodopa in the MPTP-lesioned nonhuman primate model of Parkinson's disease. Mov Disord 23:1922-1925.

Visanji NP, Fox SH, Johnston T, Reyes G, Millan MJ, and Brotchie JM (2009a) Dopamine D3 receptor stimulation underlies the development of L-DOPA-induced dyskinesia in animal models of Parkinson's disease. Neurobiol Dis 35:184-192.

Visanji NP, Fox SH, Johnston TH, Millan MJ, and Brotchie JM (2009b) Alpha1-adrenoceptors mediate dihydroxyphenylalanine-induced activity in 
1-methyl-4-phenyl-1,2,3,6-tetrahydropyridine-lesioned macaques. J Pharmacol Exp Ther 328:276-283.

Visanji NP, Gomez-Ramirez J, Johnston TH, Pires D, Voon V, Brotchie JM, and Fox $\mathrm{SH}$ (2006) Pharmacological characterization of psychosis-like behavior in the MPTP-lesioned nonhuman primate model of Parkinson's disease. Mov Disord 21: 1879-1891.

Weintraub D, Koester J, Potenza MN, Siderowf AD, Stacy M, Voon V, Whet teckey J, Wunderlich GR, and Lang AE (2010) Impulse control disorders in Parkinson disease: a cross-sectional study of 3090 patients. Arch Neurol 67: 589-595.

Wolz M, Löhle M, Strecker K, Schwanebeck U, Schneider C, Reichmann H, Grählert X, Schwarz J, and Storch A (2010) Levetiracetam for levodopa-induced dyskinesia in Parkinson's disease: a randomized, double-blind, placebo-controlled trial. $J$ Neural Transm (Vienna) 117:1279-1286.

Wong KK, Alty JE, Goy AG, Raghav S, Reutens DC, and Kempster PA (2011) A randomized, double-blind, placebo-controlled trial of levetiracetam for dyskinesia in Parkinson's disease. Mov Disord 26:1552-1555.

Wright A, Lees AJ, and Stern GM (1987) Mesulergine and pergolide in previously untreated Parkinson's disease. J Neurol Neurosurg Psychiatry 50:482-484.

Yan T, Rizak JD, Yang S, Li H, Huang B, Ma Y, and Hu X (2014) Acute morphine treatments alleviate tremor in 1-methyl-4-phenyl-1,2,3,6-tetrahydropyridinetreated monkeys. PLoS One 9:e88404.
Zeng BY, Iravani MM, Jackson MJ, Rose S, Parent A, and Jenner P (2010) Morphological changes in serotoninergic neurites in the striatum and globus pallidus in levodopa primed MPTP treated common marmosets with dyskinesia. Neurobiol Dis 40:599-607.

Zhang D, Bordia T, McGregor M, McIntosh JM, Decker MW, and Quik M (2014) ABT089 and ABT-894 reduce levodopa-induced dyskinesias in a monkey model of Parkinson's disease. Mov Disord 29:508-517.

Zhang D, Mallela A, Sohn D, Carroll FI, Bencherif M, Letchworth S, and Quik M (2013) Nicotinic receptor agonists reduce L-DOPA-induced dyskinesias in a monkey model of Parkinson's disease. J Pharmacol Exp Ther 347:225-234.

Zhang D, McGregor M, Bordia T, Perez XA, McIntosh JM, Decker MW, and Quik M (2015) $\alpha 7$ nicotinic receptor agonists reduce levodopa-induced dyskinesias with severe nigrostriatal damage. Mov Disord 30:1901-1911.

Zubair M, Jackson MJ, Tayarani-Binazir K, Stockwell KA, Smith LA, Rose S, Olanow $\mathrm{W}$, and Jenner P (2007) The administration of entacapone prevents L-dopa-induced dyskinesia when added to dopamine agonist therapy in MPTP-treated primates. Exp Neurol 208:177-184.

Address correspondence to: Philippe Huot, Montreal Neurological Institute, 3801 University St, BT 209, Montreal, QC, Canada H3A 2B4. E-mail: philippe.huot@mcgill.ca 